\title{
Uluslararası Terörizmin Değișen Yapısı ve Terör Örgütlerinin Sosyal Medyayı Kullanması: Suriye’de DAEŞ ve YPG Örneği
}

Changing Nature of International Terrorism and the Use of Social Media by Terrorist Organizations: The Cases of DAESH and YPG in Syria

\author{
Atahan Birol KARTAL ${ }^{*}$
}

\begin{abstract}
Öz:
Güvenlik sorunu ve terörizm çok eski olgulardır. Geniş kitleler üzerinde endişe ve korku yaratarak dikkat çekmek isteyen terörizme karşı insanlar tedbir almaya başlamıştır. Öncelikle terör faaliyetlerine karşı askerî tedbirler alınmış, terörizmin bertaraf edilmesi için devletlerin ortak çabalar oluşmuş ve toplumların en az zarar görmesine çalışılmıştır. Zaman içerisinde devletlerin terör unsurlarını amaçları doğrultunda kullandiğı da görülmüştür. Soğuk Savaş esnasında kontrol altında olan bu unsurlar bu dönemin ardindan kontrolden çıkmaya, daha güçlü ve daha kontrolsüz bir şekilde görünmeye başlamıştır. Terör grupları geleneksel yöntemlerin dişında teknolojiden ve sosyal medyadan daha fazla faydalanarak eylemlerini daha görünür hale getirmiştir. Gelişen teknoloji ve sosyal medya, güvenlik yapılanmast içerisindeki unsurlarca da etkin olarak kullanılmaya başlamıştır. Teröre karşı savaşta, teknolojinin etkin kullanılması, hak ve özgürlüklerin sinırlandırlmamasının etkili olacă̆ değerlendirilmektedir. Bu makalede, uluslararası terörün değişen yüzü ve terörün uluslararasılaşması konusu incelenecektir. Terör örgütlerinin sosyal medyayı kullanmasının terör faaliyetlerinin etkisini artırdiğı değerlendirilecektir.
\end{abstract}

Anahtar Kelimeler: Uluslararası Terörizm, Sosyal Medya, Küreselleşme, Terör Örgütü, Güvenlik.

* Dr. Öğr. Üyesi, Beykent Üniversitesi, İ̈BF, Siyaset Bilimi ve Kamu Yönetimi (İng.) Bölüm Başkanı, e-posta: atahankartal@yahoo.com.tr, atahankartal@ beykent.edu.tr.

Geliş Tarihi/Received: 26.01.2018

Kabul Tarihi/Accepted: 16.04.2018 


\section{Abstract:}

Security and terrorism are very old concepts. People take precautions against terrorism, which aims to draw attention through spreading fear and disturbance among large masses. Therefore, military precautions have been taken against terrorist activities. Nations have adopted cooperative ways to eliminate terrorism and secure minimum damage for societies. It is observed that governments have also used terrorist elements, which were under control during Cold War. When Cold War was over, they became uncontrollable and stronger. In addition to conventional methods, terrorist groups began to benefit from technology, which made their actions more visible, tangible, and notable. They also began to use media more. Naturally, authorities have also begun to employ advanced technology actively during the war against terrorism. Security authorities also use media actively. It has been acknowledged that effective use of technology during the war against terrorism, without limiting civil rights and liberties, would be effective against terrorism. This article analyses the changing face of terrorism and its internationalization. The article also discusses increasing effects of terrorism as terrorist organizations actively use social media.

Keywords: International Terrorism, Social Media, Globalization, Terror Organization, Security.

\section{Giriş}

Soğuk Savaş döneminde hâkim yaklaşım olan realizm uluslararası alanda güvenliğin askerî önlemlerle alınacağını savunmuştur. Soğuk Savaş'ın bitiminde ise güvenliğin sağlanmasının yanında, sürdürülmesi ve bunları gerçekleştirirken özgürlüklerin de korunması gerektiği öne sürülmüştür. Soğuk Savaş'ın bitmesi ve Sovyetler Birliği'nin dağılması, sonucunda ortaya güç boşluğu çıkarmıştır. Güç boşluğu güvenlik anlayışının Soğuk Savaş'ın bitimiyle terörizm karşısında savaş vermesi gerekliliğini ortaya koymuştur. Bu dönemde yıllardır açık bir şekilde ortada olan ideolojik kutuplaşma sonucunda taraflar kendi ötekilerini yaratmıştır. Bu yaratılan öteki, Soğuk Savaş'ın bitimiyle birlikte belirsiz hale gelmiştir, ancak 11 Eylül 2001'de Dünya Ticaret Merkezi'ne yapılan saldırılarla birlikte bu belirsizlik ortadan kalkmıştır. "Terörle Savaş" adına oluşturulan öteki, bu boşluğu doldurmuştur. Orta Doğulu Müslümanlar ve Afrikalılar bu ötekileştirmede ön plana çıkmıştır. Suriye İç Savaşı sonucu ortaya çıkan ve özellikle Avrupa'ya yönelik olan yoğun göç dalgası da bu ötekileştirmeyi daha da arttırmıştır. 
Uluslararası Terörizmin Değişen Yapısı ve Terör Örgütlerinin

Sosyal Medyayı Kullanması: Suriye'de DAEŞ ve YPG Örneği

$\mathrm{Bu}$ çalışmanın ana amacı, uluslararası güvenlik tehditlerini ve uluslararası terörizmi, bunun yanı sıra terör örgütlerinin sosyal ve elektronik medya ile ilişkisini ve bunu nasıl kullandıkları konusunu araştırmaktır. Soğuk Savaş sonrası uluslararası terör değişmiştir. Bu değişiklikte özellikle sosyal medyanın etkisi çok büyüktür. Terör örgütleri geçmişte daha dar kapsamlı ve kısmen yakın yerlerde eylem yaparken; günümüzde uluslararası faaliyet yürüten, sınırları aşan, daha karmaşı ve bulunduğu yerlere daha kolay adapte olan yapılar haline gelmiştir. İnsanlık tarihinden beri var olan ve hedef kitlesi çok geniş olan terörist faaliyetlerin önüne geçmek çok zordur. Özellikle son y1llarda gelişen teknolojik imkânlar ve gelişen dünya, her alanda olduğu gibi terör örgütlerinin de işlerini kolaylaştırmıştır. Gelişen teknolojiyle birlikte terör örgütleri yeni imkân ve kabiliyetler kazanmıştır.

Demokratikleşme adına atılan atımlar ülkelerde terörün sayısal olarak azalmasına neden olmakla birlikte, teknolojik olarak gelişmiş medyanın ve kitle iletişim araçlarının etkisiyle etkinliği artmıştır. İnsanların kendilerini özgürce ifade etmesi, düşüncelerini söyleyebilmesi ve sesini yönetenlere duyurabilmesi, şiddete yönelimi azaltmıştır. Ancak farkındalık yaratmak adına medyanın ve özellikle de sosyal medyanın kullanılması, terörün etkinliğini artırmış eleman temini kolaylaşmıştır. Ülkelerde yaşayan halkın bu araçların kullanılmasılyla istismar edilmesi ve aldatılması daha kolay hale gelmiştir. Bazı çevrelerin de bu örgütleri kullanmak istemesi veya kullanması sonucunda işler daha karışık ve içinden çıkılmaz bir hal almıştır.

Baskı unsuru olarak terörü görmek isteyen bazı çevreler, terörü araç olarak kullanmaya devam edecektir. Terörizmin devletler tarafindan bir savaş olarak algılanması, askerî önlemlerin artmasına ve güvenlikle ilgili üretilecek politikaların uygulanmasına ya da yeniden düzenlenmesine sebep olmuştur. Ayrıca devletler tarafindan eğitim, kültür, ekonomi, hukuk ve sosyal politikalarda da yeniden düzenlemeler yapılarak terörizmle mücadele edilmeye çalış1lmıştır. Üzerinde durulması gereken ana konu terörizm ile topyekûn mücadeledir; çünkü bir devlet için bu, oldukça hassasiyet gerektiren bir konudur. Terör örgütleri silahlı mücadeleyi araç olarak kullanır ve devletten bazı konularda değişiklik yapmasını ister. Bu örgütler sürekli şiddet uygulayarak, bir anlamda, 
bu şiddeti bastırmada devleti de bu şiddete çekerek devletin halk arasında

Güvenlik

Stratejileri

Y11: 14

Say1: 27 meşruiyetini sorgulanır hale getirmeyi hedefler. Devletler, terörle hukuk içerisinde mücadele etmelidir. Demokratik bir düzen içerisinde evrensel ilkelerden uzaklaşılmaması gereklidir. Aksi durum terör örgütlerinin istismar alanlarını genişletmesine, amaçlarını haklı hale getirmesine ve eleman temininde güçlük çekmemesine olanak tanır.

Medyanın esas görevi, kişilerin haber alma ihtiyacını karşılamaktır. Ancak bunu yaparken son derece hassas ve dikkatli olmalıdır. Medya terörle mücadeleye destek vermelidir. Spikerlerin haberi veriş şeklinden gelen görüntülere; basında çıkan haberlerden ve başlıklardan haberin veriliş şekline kadar çok dikkatli olunmalıdır. Terör örgütlerine bilmeden de olsa destek verilmemeli ve terör propagandası olabilecek haberlerden kaçınılmalıdır. Makalede terörün yeni yüzü anlatılırken, özellikle devletin medyayı kullanması ve terör örgütlerinin sosyal medyayı kullanması üzerinde durulacaktır. Suriye'de terör örgütlerinin bu konudaki çabaları incelenecektir.

\section{Terörizm Üzerine Tanımlamalar ve Gelişimi}

Terör sözcügü kök itibari ile Latinceden gelmiştir. Latince "terrere" sözcügünün türemesi ile ortaya çıkmıştır. Korku salmak, yıldırmak ve dehşete düşürmek anlamına gelir. ${ }^{1}$ Türk Dil Kurumu Büyük Türkçe Sözlüğü tarafindan terör, "yıldırı" olarak; terörizm ise "yıldırıcıllk" olarak tanımlanmıştır. ${ }^{2}$ Ancak Türkçe sözlükteki tanımın insan üzerinde fazla bir korku yaratmadığı, dehşete düşürmediği ve etkisinin az olabileceği düşünüldüğünde, terör veya terörizmin orijinal şekliyle kullanılmasının daha uygun olacağı değerlendirilmektedir; çünkü bu yıldırı veya yılmak kelimesi insanda bir şeyi zorla yapmaktan bıkmak ve usanmak anlamına gelebileceğinden terörün anlamını yumuşatmaktadır.

${ }^{1}$ Sertaç Başeren, "Kavramsal Özellikleri ile Terörizm”, Küresel Terörizm ve Uluslararası İsbirliği Sempozyumu, 23-24 Mart 2006, Genelkurmay Basımevi, Ankara, 2006, s. 7.

2 "Terör", http://www.tdk.gov.tr/index.php?option=com_bts\&arama=kelime\&guid= TDK. GTS.5a3028e10c5ce2.79615890 (Erişim Tarihi: 31.11.2017). 
Uluslararası Terörizmin Değişen Yapısı ve Terör Örgütlerinin

Sosyal Medyayı Kullanması: Suriye'de DAEŞ ve YPG Örneği

Terör, 12 Nisan 1991 tarihinde yayınlanan 3713 sayılı Terörle Mücadele Kanununda şu şekilde tanımlanmıştır: "Cebir ve şiddet kullanarak; bask1, korkutma, yıldırma, sindirme veya tehdit yöntemlerinden biriyle, Anayasa'da belirtilen Cumhuriyet'in niteliklerini, siyasî, hukukî, sosyal, laik, ekonomik düzeni değiştirmek, Devletin ülkesi ve milletiyle bölünmez bütünlügünü bozmak, Türk Devleti'nin ve Cumhuriyet'in varlığını tehlikeye düşürmek, Devlet otoritesini zaafa uğratmak veya y1kmak veya ele geçirmek, temel hak ve hürriyetleri yok etmek, Devletin iç ve diş güvenliğini, kamu düzenini veya genel sağlığı bozmak amaciyla bir örgüte mensup kişi veya kişiler tarafindan girişilecek her türlü suç teşkil eden eylemlerdir."’3

Terörizmin orijinine bakarsak, tüm insanlık tarihinde sistematik olarak örgütlenmiş gruplar vardı. Romalı bir Yahudi tarihçi olan Josephus Flavius yazılarından, Roma'nın Filistin'i işgal etmesiyle, aşırı bir Yahudi grup olan Sicari hakkında çok şey öğrenmekteyiz. Sicariler köktenci ve aşırı yurtseverdir. Çoğunlukla diğer Yahudilere gün ışı̆̆ında, tatil günü kutlamalarında paltoları veya elbiselerinin altında sakladıkları Sica denen kısa bir hançerle saldırmaktaydılar. Saldırılar parası olanlara, rahiplere ve herkese karşıydı. Bunlar arşivleri yaktılar, sarayları ateşe verdiler. Şehir dışında Romalılara karşı gerilla savaşı yaparken, şehir içinde yani Kudüs'te terörist faaliyetler uyguladılar. ${ }^{4}$ Eylemlerde önemli olan, kişilerin vahşice öldürülüp bunun da birçok kişi tarafından izlenmesiydi. Eylemlerde korku salmak ve amaçlanan siyasi hedefe ulaşmak önemliydi. ${ }^{5}$ Bunları yaparken, dehşet saçarak ve endişe yaratarak halkı baskı altına almak istemişlerdi.

Terörizmin ilk örneklerine başka bir örnek ise Haşhaşilerdir. Bu tarikatın kurucusu Hasan Sabbah, Kuzey İran'da Kum kentinde dünyaya gelmiştir. Haşhaşiler dağlık alanda bulunan birçok kaleyi aldı ve bunların

\footnotetext{
3 “Terörle Mücadele Kanunu”, http://www.mevzuat.gov.tr/MevzuatMetin/1.5.3713.pdf (Erişim Tarihi: 15.01.2018).

${ }^{4}$ Walter Laqueur, The New Terrorism, Oxford University Press, Oxford, 1999, s. 10.

${ }^{5}$ Selim Kanat vd., "İnsani Güvenlik ve Terörizm ile Mücadele", Süleyman Demirel Üniversitesi İktisadi ve İdari Bilimler Fakültesi Dergisi, 2016, s. 570.
}

\section{3}

Güvenlik Stratejileri

Y11: 14

Say1: 27 

ilki olan Alamut 1090 yılında ele geçirildi. Daha sonra faaliyetlerini şehir merkezlerine kaydırmaya başladılar. İlk şehir suikastları Büyük Selçuklu Sultanlığının Başveziri Nizamülmülk’e karşı olmuştur. Takip eden y1llarda Haşhaşiler Suriye, Filistin ve İran'da faaliyetlerini sürdürdü. Çoğunlukla Sünniler ve aynı zamanda Hıristiyanları öldürdüler. Hareketlerinde büyük bir gizlilik ve ustalık vardı. ${ }^{6}$ Haşhaşiler, uyuşturucu vererek kendisine bağladığı grupları itaatkâr ve disiplinli hale getirmiş ve uzun süreli bir oluşumla kendisi için siyasi kazanımlar elde etmek amacıyla çalışmıştır. Eylem şekilleri sebebiyle, İngilizce'de "suikastçı" anlamına gelen "assassin" kelimesi Haşhaşi kelimesinden türemiştir. Bir diğer açıdan bu konuya bakarsak, terörizm ile uyuşturucunun bir araya geldiği görülmektedir.?

$\mathrm{Bu}$ örnekleri çoğaltmak gerekirse, modern anlamda terörün ortaya çıkışı olarak kabul edilen Fransa İhtilalı sonrası kurulan Cumhuriyet rejiminde, Maximillien Robespierre, ülke yönetiminde yeni rejime karşı kentlerde ortaya çıkan ayaklanmaları bastırmak için askerî birlikler görevlendirmiş ve bu dönemde icat edilen giyotinle binlerce kişiyi halkın önünde idam ettirmiştir. Bu cezalandırma yöntemiyle halk arasında korku ve endişe yaratılmak istenmiştir. Bu döneme "terör rejimi” adı verilmektedir. Bu dönem, şimdi anlaşılanın aksine yararlı olarak değerlendirilmiştir. $\mathrm{Bu}$ dönemde uygulanan terör, devlet düzeninin sağlanması adına devlet tarafından uygulanmıştır.

Daha sonra 19. yüzyılın sonlarına doğru Rusya'da Çarlık rejimiyle mücadele etmek adına "Narodnaya Volya" (Halkın İradesi) denilen bir grup kurulmuş; bunlar da şiddeti halkın ilgisini çekmek ve bilinçlendirmek için kullanmıştır. Örgüt rastgele şiddet yerine sembolik eylemlere yönelmiştir.

20. yüzyılın başlarında faşist Nasyonel Sosyalist partilerin yönetimi ellerinde bulundurmasıyla terör kullanılarak baskı ve korku ile bu ülkeler içerisinde bir sistem oluşturulmuştur. Terörizm devlete düşman

\footnotetext{
${ }^{6}$ Walter Laqueur, age, s. 11.

${ }^{7}$ Selim Kanat vd., agm, s. 570.
} 
Uluslararası Terörizmin Değişen Yapısı ve Terör Örgütlerinin

Sosyal Medyayı Kullanması: Suriye'de DAEŞ ve YPG Örneği

olarak görülen muhaliflerin üzerinde baskı kurmak için kullanılmıştır. Hitler Almanyasında sadece muhaliflere değil, sisteme bağlı olsalar da ırkçı ve dini nedenlerle Yahudi ve Çingenelere de bu baskı uygulanmış; Güvenlik Stratejileri aynı zamanda korku yaratılmıştır. Savaş öncesinde ve esnasında devam Y11: 14 eden Hitler terörizmi, milyonlarca kişinin ölümüne sebep olmuştur. ${ }^{8}$

İkinci Dünya Savaşı sonrasında Doğu-Batı Bloğu ya da NATOVarşova Paktı diyebileceğimiz bloklaşma sonucunda oluşan denge, sıcak savaş ihtimalini azaltmış; nükleer dengenin kurulmasıyla hem Amerika Birleşik Devletleri (ABD), hem de Sovyetler Birliği savaştan kaçınmıştır. Ancak terörizm bu dönemde devletlerin düşman olarak nitelendirdiği devletleri zayıflatmak veya kendi yanına çekmek için kullandığ 1 bir araç haline gelmiştir. Devletler birbirine fiilen saldırmamış; bunun yerine üçüncü bir taraf kullanılarak mücadelelerini sürdürmüştür. Yani Vekâlet Savaşı uygulanmıştır. El-Kaide örgütünün Afganistan'da Sovyetler Birliği'ne karşı Amerikan ve Suudi fonlarıyla desteklendiği ve bazı analizciler tarafından CIA tarafından eğitime tabi tutulduğu düşünülürse, terör örgütlerine verilen desteklerin ne kadar yanlıș politikalar olduğu açıktır. Bu örgütün, karargâhını ve eğitim kamplarını Afganistan'a taşıyıp Taliban ile yakın ilişki içersinde olması ve 11 Eylül saldırılarını gerçekleştirmesi, bunun en güzel örneğidir. ${ }^{9} \mathrm{Bu}$ ortamda terörizm, devlet terörizminin görüldüğü bir önceki dönemden çıkarak devlet destekli teröre dönüşmüştür. $\mathrm{Bu}$ dönemde, terörizm, aynı zamanda, sömürgeci devletlere karşı tam bağımsızlık mücadelesi veren sömürge devletlerinin bağımsızlık yolunda kullandıkları yollardan biri haline gelmiştir. Soğuk Savaş boyunca Marksist-Leninist ideolojiyi benimseyen gruplar, Sovyetler Birliği’ne şirin görünmek için eylemler yapmış ve Doğu Bloğu devletleri de bunlara destek vermiştir. Batılı ülkeler de bu örgütlere karşı devletin şiddet kullanarak mücadelesini bir ölçüde maruz görmüştür.

\footnotetext{
${ }^{8}$ Agm, s. 571.

9 “Al-Qaeda's origins and links", http://news.bbc.co.uk/2/hi/middle_east/1670089.stm (Erişim Tarihi: 24.01.2018).
} 
Terörizmin tanımlamasını yapmak gerekirse, birbirine benzer ama

Güvenlik Stratejileri

Y11: 14

Say1: 27 bir o kadar da farklılık gösteren tanımlamalarla karşı karşıya kalabiliriz. 1936 ilâ 1981 yılları arasında 109 terörizm tanımı yapılmıştır. ABD Dışişleri Bakanlı̆̆ı'nın yaptığı tanıma göre "terörizm, yerel gruplar veya gizli ajanlar tarafından muharip olmayan hedeflere karşı yapılan önceden tasarlanmış, siyasi olarak motive edilen şiddet" anlamına gelir. ${ }^{10}$ Aynı zamanda, terörizmi, siyasi amaçlar için örgütlü olarak sistemli ve devamlı terör kullanmayı metot olarak kullanan ve bir strateji anlayışı olarak ya da insanları yıldırmak sindirmek yoluyla onlara belli düşünceleri benimsetmek için zor kullanma ya da tehdit eylemi olarak tanımlayabiliriz. ${ }^{11}$ Ayrıca, Hüseyin Kazan'ın aktardığına göre, Meydan Larousse, terörizmi ihtilalcı grupların giriştiği şiddet eylemlerinin tümü, tedhişçilik; bir hükümet tarafindan uygulanan şiddet rejimi olarak; Ana Britannica ise halka ve bireylere karşı sistemli şiddet eylemlerine başvurma olarak tanımlamıştır. "Organize bir grubun veya partinin, açıkça beyan edilen amaçlarını şiddetin başlıca sistematik kullanım yöntemleri ile başarmaya çalıştığı metodun arkasındaki metot veya teoriyi tanımlamakta kullanılan bir terimdir" diyerek terörü tanımlayan Mesut Hakkı Caşın, şiddetin sistematik kullanımı üzerine vurgu yapmış ve genel olarak topluluklara karşı onaylanmamış bir şiddet olarak değerlendirmiştir. ${ }^{13}$ Elşen Memmedli de terörizmi siyasetin en radikal biçimi ve silahla yapılan savaşın en uç tarafi olarak tanımlarken; cebir şiddet kullanarak baskı korkutma ve y1ldırma veya tehdit yöntemlerinin biriyle devletin anayasal sistemini, siyasi, hukuki, laik ve ekonomik düzeni değiştirmek, devletin varlığını tehdit etmek, toprak bütünlügünü ortadan kaldırmaya çalışmak,

10 “Terörizm”, https://www.state.gov/documents/organization/65464.pdf (Erişim Tarihi: 20.01.2018).

${ }^{11}$ Mevlüt Bozdemir, “Terör (mü) ve Terörizm (mi) ?”, S.B.F. Basım Yayım Yüksek Okulu Yıllı̆̆

${ }^{12}$ Hüseyin Kazan, "Terör Medya İlişkisi ve Medya Terör Haberciliği”, Güvenlik Stratejileri Dergisi, 2016, Y1l 13, Say1 24, s. 115.

${ }^{13}$ Mesut Hakkı Caşın, Uluslararası Teröriżm, Nobel Yayın Dağıtım, Ankara, 2008, s. 99-100. 
Uluslararası Terörizmin Değişen Yapısı ve Terör Örgütlerinin

Sosyal Medyayı Kullanması: Suriye'de DAEŞ ve YPG Örneği

devletin otoritesini yok etmek ya da yıkmak, vatandaşların sahip olduğu hak ve hürriyetleri ortadan kaldırmak, ülkenin iç ve dış güvenliğini tehdit etmek ve yok etmeye çalışmak halkın sağlığını tehdit etmek ve sonunda kamu düzenini bozmak amacıyla suç oluşturan her türlü yapılan eylemler olarak tanımlamıştır. ${ }^{14}$ ABD'nin 2003 yılında “Terörle Mücadele Ulusal Stratejisi"nde terörizm, resmî olarak, önceden tasarlanmış siyasi olarak motive edilmiş savaşmayan ve askerî olmayan hedeflere karşı yerel ve bölgesel gruplar ile gizli ajanlar tarafindan suç işlemektir şeklinde tanımlamıştır. ${ }^{15}$ Daha önceki tanımlamalarda belirttiğimiz gibi terörizm, belirlenen amaçlar doğrultusunda asıl hedefler dışında rastgele seçilen hedeflere halkta panik, korku, umutsuzluk ve yılgınlık yaratmak için düzenli olarak şiddet kullanmak olarak tanımlanabilir.

Özetlemek gerekirse, terörü, siyasal bir şiddet ve halkın arasında korku ortaya çıkarabilmek için etki yaratmanın yanı sıra, şiddet ve zor kullanılması, bir siyasi amaç adına yapılması, korkutma, dehşet korku salma, tehdit, toplumda ve terör eyleminin gerçekleştirildiği yerdeki kurbanların dışındaki halktan beklenen tepki olarak uyandırdığı psikolojik etki olarak tanımlayabiliriz. ${ }^{16}$ Bunun yanı sıra, terörizmin tanımında bazı benzer ve temel alanlar vardır. Bunlar vahşi, korkunç, nefret uyandırıcı "yasa dışı terörist eylemler", masum ve savaşçı olmayan "terörist hedefler", bunun yanı sıra siyasi ikna ve etki sağlayan "terörist amaçlar"dır. Bunlara ayrıca "terörizmin faillerini" ekleyebiliriz. ${ }^{17}$

\section{Uluslararası Terör ve Tanımı}

Soğuk Savaş sonrasında güvenlik tehditleri küreselleşmeyle birlikte değişikliğe uğramış; bu dönemde ortaya çıkan tehditlerden daha çok

\footnotetext{
${ }^{14}$ Elşen Memmedli, “Güvenlik Tehditleri ve Uluslararası Terörizm”, Süleyman Demirel Üniversitesi Sosyal Bilimler Enstitüsü Dergisi, 2016, s. 988.

15 "Terörizm", National Strategy for Combating Terrorism https://www.state.gov/ documents/organization/60172.pdf (Erişim Tarihi: 12.01.2018).

${ }^{16}$ Doğu Ergil, "Uluslararası Terörizm”, Ankara Üniversitesi Siyasal Bilgiler Fakültesi Dergisi, 1992, Cilt: 47, Say1: 3,s. 140.

${ }^{17}$ Donald M. Snow, Terrorism: The Changing Global Threat, Cases in International Relation, Longman, New York, 2012, s. 308-309.
} 
sosyo-ekonomik konular daha baskın hale gelmiştir. 2003 yılında yayınlanan "Avrupa Güvenlik Stratejisi”, küreselleşmeyle ortaya çıkan

Güvenlik

Stratejileri

Y11: 14

Sayı: 27 yeni tehditleri, terörizm, kitle imha silahlarının yayılması, bölgesel çatışmalar, başarısız devletler ve organize suçlar olarak ortaya koymuştur. Bütün bu tehditlerin birbiriyle bağlantısı olabilmektedir. ${ }^{18}$ Örnek olarak, terör örgütlerinin kitle imha silahlarına ulaşabilmesi için organize suç örgütleri ile iş birliğine gitmesini ya da organize suç örgütlerinin insan, silah ve malzeme kaçakçıllğında terör örgütlerinin imkânlarından faydalanmasını, sınır geçişlerinde onların tecrübelerini ve himayesini kullanmasını sayabiliriz. Bunun yanı sıra, güvenlikle ilgili algılamalar sınır geçişleri, terör örgütlerinin uluslararasılaşması, terör örgütü elemanlarının birçok milletten teşkil edilmesi, terörle ilgili sorunların birçok ülkeyi ilgilendirmesi ve suçların sınırı aşan şekilde gerçekleşmesi, artık tüm problemlerin tek bir devlet için problem oluşturmamasını, uluslararası tüm aktörlerin terörle mücadeleye topluca katılmasını sağlamıştır.

Bugün uluslararası terörizmi engelleme açısından devletlerin imza koyduğu 12 adet evrensel anlaşma bulunmaktadır. 2001 yılındaki 1373 sayılı Birleşmiş Milletler (BM) Güvenlik Konseyi Kararı ile tüm devletlere bu anlaşmalara taraf olma ve uygulama yükümlügü getirmiştir: ${ }^{19}$

- Uçaklarda İşlenen Suçlar ve Diğer Eylemlerle ilgili Sözleşme (1963),

- Uçakların Yasadışı Olarak Ele Geçirilmesinin Önlenmesi Sözleşmesi (1970),

- Sivil Havacılığın Güvenliğine Karşı Kanunsuz Hareketlerin Önlenmesi Sözleşmesi (1971),

- Uluslararası Sivil Havacilığa Hizmet Veren Hava Alanlarında Kanunsuz Şiddet Eylemlerinin Önlenmesi İle İlgili Protokol (1988),

${ }^{18}$ Elşen Memmedli, agm, s. 992.

${ }^{19} 1373$ sayılı Birleşmiş Milletler (BM) Güvenlik Konseyi Kararı, http://www.uhdigm. adalet.gov.tr/uhamer/Ter\%C3\%B6rle\%20\%C4\%B0lgili\%20Uluslararas\%C4\%B1\%20Belg eler/birle\%C5\%9Fmi\%C5\%9F\%20milletler/BM\%20G\%C3\%BCvenlik\%20Konseyi $\% 201$ 373\%20Say\%C4\%B11\%C4\%B1\%20Karar\%C4\%B1.pdf (Erişim Tarihi: 23.12.2017). 
Uluslararası Terörizmin Değişen Yapısı ve Terör Örgütlerinin

Sosyal Medyayı Kullanması: Suriye'de DAEŞ ve YPG Örneği

- Uluslararası Korunan Kişilere Karşı İşlenen Suçların Önlenmesi ve Cezalandırılması Sözleşmesi (1973),

- Rehin Alma Olaylarına Karşı Uluslararası Sözleşme (1979),

- Nükleer Maddelerin Fiziksel Korunması Hakkında Sözleşme (1980),

- Denizcilik Seyrüsefer Güvenliğine Karşı Yasadışı Eylemlerin Önlenmesi Sözleşmesi (1988),

- Kita Sahanlığı Üzerinde Bulunan Sabit Platformların Güvenliğine Karşı Kanunsuz Eylemlerin Önlenmesi Protokolü (1988),

- Plastik Patlayıcıların Tespit Edilmesi Amacıyla İşaretlenmesi Hakkında Sözleşme (1991),

- Terörist Bombalamaların Önlenmesi Uluslararası Sözleşmesi (1998),

- Terörizmin Finansmanının Önlenmesi Uluslararas1 Sözleşmesi (1999). ${ }^{20}$

Terörün sınır ötesine taşınması, uluslararası bir etki ve sonuçlar doğurmaktadır; bu da uluslararası terörizmi meydana getirmektedir. ${ }^{21}$ Terörizm yabancılara ait hedeflere yönelirse, bir veya birden fazla hükümet ve devlet tarafindan desteklenirse, başka bir hükümeti veya uluslararası örgütleri etkilemek için yapılırsa, uluslararası hukuku hedef alan faaliyetlerde bulunursa, devletler arasında çözülmesi çok uzun zaman alacak sorunlar ortaya çıkaracaksa, uluslararası barış ve güvene tehdit oluşturuyorsa, uluslararası hale gelir. ${ }^{22}$ Mesela Türkiye'ye sığınmacı olarak giren Suriye vatandaşı Nabil Fadlı'nın dünyaca tanınan ve bilinen bir yer olan İstanbul'un Sultanahmet Meydanı'nda 11 Alman turistin ölümüne, üç Alman, iki Norveçli, iki Perulu ve iki Türkün yaralanmasına sebep olan intihar saldırısı tam

${ }^{20}$ Harun Semercioğlu, "Uluslararası Terörizmde Küresel İşbirliği: Bir Ütopya”, Hacettepe Üniversitesi İktisadi ve İdari Bilimler Fakültesi Dergisi, 2016, s. 103-104.

${ }^{21}$ Tuğçe Gençtürk, "Terör Kavramı ve Uluslararası Terörizme Farklı Yaklaşımlar”, http://sam. baskent.edu.tr/makaleler/tgencturk/TerorUluslararasi.pdf (Erişim Tarihi: 17.01.2018).

${ }^{22}$ Harun Semercioğlu, agm, s. 100-101. 

olarak uluslararası terörizme bir örnektir, ${ }^{23}$ çünkü bu sınırı aşan bir saldırıdır ve yapan yabancı bir ülkenin vatandaşıdır. Yaptığ 1 eylem, hedeflediği kişiler ve etkisi açısından sadece Türkiye'yi değil, diğer ülkeleri de etkilemiştir. Harun Semercioğlu uluslararası terörizmi "gözetilen hedef, gerçekleştirilen eylemler ve kaynakları itibariyle birden fazla devleti ilgilendiren ve uluslararası sonuçlar doğuran terörist faaliyetler" olarak tanımlamıştır. ${ }^{24}$ Uluslararası terörizm, aynı zamanda, kabul edilmiş uluslararası savaş ve diplomasi kuralları dışında sürdürülen şiddet kampanyaları ve eylemleri olarak tanımlanabilir. Kuralların ihlali, diplomatlara ve diğer uluslararası korunan kişilere saldırmayı, uluslararası seyahat ve ticarete saldırmayı veya milletlere çeşitli yollarla şiddet ihraç etmeyi içerebilir. ${ }^{25}$ Bütün bu tanımlar ve açıklamaların ışığında, uluslararası terörizm; sınırları aşan, elemanları çok uluslu olan, yaptığ kapsayan, ortaya çıkardığı sorunların birçok ülkeyi ilgilendirdiği, yerel hedefler dışında yabancı hedeflere yönelen, başka devletler tarafindan desteklenen ve uluslararası örgütleri, devletleri ve hukuku etkileyen terör faaliyetleri olarak tanımlanabilir.

Uluslararası terörizm ile organize suçların birbiriyle iç içe geçtiği, hatta karıştırıldığı da olmaktadır. Bunların her ikisinin de devletlerin birbiriyle ilişkilerine ve uluslararası güven ortamına zarar verdiği açıktır. “Organize suçlar” terimi, ilk kez ABD' de Birinci Dünya Savaşı sonrası kullanılmaya başlanmış; ardından İkinci Dünya Savaşı'ndan sonra "mafya" terimine dönüşmüştür. Soğuk Savaş'ın ardından bu örgütler uyuşturucu kaçakçılığı, nükleer madde kaçakçıllı̆ 1 , silah kaçakçılığı ve sahtecilik gibi örgütlü suçlar işlemeye başlamıştır. ${ }^{26}$ Yaptıkları yasa dış1

${ }^{23}$ "Sultanahmette Canlı Bomba Dehşeti", https://www.sabah.com.tr/gundem/ 2016/01/13/sultanahmette-canli-bomba-dehseti (Erişim Tarihi: 18.01.2018).

${ }^{24}$ Harun Semercioğlu, agm, 100.

${ }^{25}$ Brian M. Jenkins," International Terrorism: A New Kind of Warfare", The Rand Corporation, Santa Monica, 1974, s. 2.

${ }^{26}$ Seda Öz Yıldız, "Makarenko'nun "Kara Delik Sendromu" Teorisi ve Terörizm Finansmanında Sınırıaşan Organize Suçlar", Güvenlik Stratejileri Dergisi, 2017, Yıl: 13, Say1: 25, s. 29-30. 
Uluslararası Terörizmin Değişen Yapısı ve Terör Örgütlerinin

Sosyal Medyayı Kullanması: Suriye'de DAEŞ ve YPG Örneği

faaliyetlerin bu dönemdeki artışının en önemli sebepleri arasında,

Sovyetler Birliği'nin dağılması sonucu ortaya çıkan güç boşluğunu, Güvenlik ayrıca Sovyetler Birliği'ne ideolojik yakınlığı olan Doğu Avrupa Stratejileri ülkelerinde de sistemin değişmesini, bu ülkelerde artan yolsuzluk ve Y11: 14 yoksulluk sebebi ile daha önce devlet kontrolünde olan silah, malzeme Sayı: 27 ve teçhizatın yasa dişı örgütlerin eline geçmesini ve bunların pazarlanmasını sayabiliriz.

"Organize Suç Örgütü" kavramını tanımlamak gerekirse, bu kavram, doğrudan veya dolaylı olarak haksız mali veya maddi çıkar elde etmek için ağır suç veya yasa dişı eylemi gerçekleştirmek amaciyla birlikte hareket eden üç veya daha fazla kişiden oluşan yapılanmış bir grup anlamına gelmektedir. ${ }^{27}$

Organize suç örgütleri ile uluslararası terör örgütleri arasındaki farklar şu şekilde sıralanabilir:

- Organize suç örgütleri, terörist eylem taktiklerini kullanırken gelir elde etmeyi amaçlar; terör örgütleri siyasi hedeflerine ulaşmak adına yaptığ eylemlere kaynak sağlamak için organize suç işler.

- Organize suç örgütleri daha fazla gelir elde etmek isterken; terör örgütleri ideolojilerini yaymak ve gerçekleştirmek ister.

- Terör örgütleri finansal kaynaklarını silah ve mühimmat temini, örgüt giderleri, elemanlarının eğitimi ve ulaşım masrafları, sempatizan ve örgüt elemanı temini için kullanır; organize örgütler de, yukarıdaki kalemlere ihtiyacı olmasına rağmen, esas finans kaynaklarını yeni yatırımlar için kullanır.

- Organize suç örgütleri yasa dışı pazar ve gruplarla iletişim halindedir; terör örgütleri bu iletişimden fayda sağlarlar.

- Organize suç örgütleri işledikleri suçları gizlemeye çalışırken, terör örgütleri en kısa zamanda suçu sahiplenir.

27 “Türkiye Büyük Millet Meclisi Başkanlığı Sınıraşan Örgütlü Suçlara Karşı Birleşmiş Milletler Sözleşmesinin Onaylanmasının Uygun Bulunduğuna Dair Kanun (Kanun No: 4800), https://www.tbmm.gov.tr/kanunlar/k4800.html (Erişim Tarihi: 21.01.2018). 
52

Güvenlik

Stratejileri

Y11: 14

Say1: 27

- Terör örgütleri bomba, ağır silah ve biyolojik silah gibi farkındalığını sağlamak adına ses getirici eylemlerle fazla sayıdaki insanın ölümüne sebep olabilirken; organize suç örgütleri yalnızca örgüt içi cezalandırma, hiyerarşiyi sağlama, maddi çıkar sağlama yolunda engellerin ortadan kaldırılması gibi nedenlerle sadece ateşli silahlarla kitleye değil bireye karşı şiddet uygular.

$\mathrm{Bu}$ örgütlerin benzerlikleri ise aşağıdaki gibidir:

- Her ikisi de maddi gelirlerini arttırmak istemektedir.

- Her ikisinin de sınırı aşan yapısı vardır.

- Devlet görevlilerini tehdit ve adam kaçırma gibi eylemlerini gerektiği takdirde her ikisi de uygular.

- Her ikisinin de yapılanmasinda liderler, militanlar, yeraltı teşkilatı ve sempatizanları olmak üzere benzerlikler vardır. ${ }^{28}$

11 Eylül saldırıları sonrasında bir milat olarak, sınırlı alanlarda faaliyet gösteren terörizmin artık sınırları aşan bir şekil aldığı görülmüştür. $\mathrm{Bu}$ saldırılar nedeniyle terörizmin küreselleştiği, terörizmin artık yaygınlaşmaya başladığı ve dünya geneline yayıldığ kabul görmüsstür. Küreselleşmenin ve teknolojinin getirdiği firsatların, terör örgütlerinin düşman olarak gördüklerini lokal olarak bulunduğu ve konuşlandığ 1 sınırların dışında da vurmaya başlamasına olanak sağladığı, ayrıca dünyanın en zengin ve gelişmiş ülkelerinin bile vurulabildiği bir dönemde; bu durum, sokaktaki halkın psikolojik açıdan kaygı ve kuşku duymasına neden olmuştur. Ancak buna rağmen ülkeler ve hükümetler arasında uluslararası terörün engellenmesi ile ilgili olarak oydaşma tam olarak sağlanamamıştır. Amerikalıların "teröre karşı savaş" ifadesine karşı, Avrupa Birliği (AB) "terörizmle mücadele" ifadesini tercih etmiştir. $A B$ daha çok terörizm tehdidini Kuzey Afrika'dan Akdeniz ve Orta Doğu'dan Balkanlar vasitasıyla kendi topraklarına gelen göç hareketi içinden değerlendirmekte; tehdidin öncellikle Kuzey Afrika ve Orta Doğu kökenli halklardan geleceğini öngörmektedir. Kendi topraklarında yapılan eylemler

${ }^{28}$ Seda Öz Yıldız, agm, s.38-40. 
Uluslararası Terörizmin Değişen Yapısı ve Terör Örgütlerinin Sosyal Medyayı Kullanması: Suriye'de DAEŞ ve YPG Örneği

"ötekiler" tarafindan yapılan kendi istikrarına yönelik eylemler, ancak Orta Doğu'da veya Asya'da gerçekleşen eylemler iç savaş olarak değerlendirilmiştir. ${ }^{29} 11$ Eylül saldırıları Batılıları o kadar etkilemiştir Güvenlik Stratejileri ki, Batılılar terör sözcüğü ile El Kaide'yi ve Müslümanları bilinçli Y11: 14 sürdürülen propagandaların da sonucu olarak aynı yerde görmeye başlamıştır. ${ }^{30}$ Tabii, burada El Kaide'nin de insanların kafasında Say1: 27 bıraktığı imaj ve Batılıların İslam dinini algılamaları bakımından zararı en çok Müslümanlara verdiğini de unutmamak gerekir.

$\mathrm{AB}$, terörizmle mücadele kapsamında, 19 Eylül 2001 tarihli Konsey Kararı'nda terörizm kavramı ve suçlarını ele almış ve terörizmle mücadele için bir eylem planı oluşturulmuştur. Bu eylem planında polis ve adli işlerde $\mathrm{AB}$ içerisinde iş birliğini arttırma, uluslararası hukukun gereklerin yerine getirme, terörün finans kaynaklarını kurutma, 11 Eylül saldırılarında görüldüğü gibi havada güvenliği temin etme ve küresel eylemlerde koordinasyon sağlama konularına odaklanılmıştır. Daha sonra Mart 2004 Madrid ve Temmuz 2005 Londra saldırıları, Avrupa'da büyük bir öfke, kayg1 ve korku yaratmıştır. 25 Mart 2004 tarihinde toplanan Devlet ve Hükümet Başkanları "Terörizm ile Mücadele Deklarasyonu" yayınlamış ve yeni eylem planını kabul etmiştir. 2001 yılındaki eylem planından farklı olarak, bu deklarasyonda teröristlerin takibinin yapılması, sınır kontrollerinin ve güvenliğin arttırılması, terör örgütlerinin eleman kazanmasının önüne geçilmesi, $A B$ ülkelerinin terörle mücadele konusunda yardıma ihtiyaç duyan ülkelere yardım etmesi konuları konuşulmuş ve kabul edilmiştir. ${ }^{31}$

ABD ise 11 Eylül saldırılarıla birlikte uluslararası terörizm faaliyetlerinin, daha önce konumu itibariyle pek ihtimal vermemesine rağmen, kendi ülkesi içinde de olabileceğini görmüş ve topraklarını tekrar güvenilir ve Amerikalıların rahat yaşayabileceği bir yer haline

\footnotetext{
${ }^{29}$ Samet Zenginoğlu, "Uluslararası Terörizm ve Avrupa Birliği’, Süleyman Demirel Üniversitesi Sosyal Bilimler Enstitüsü Dergisi, 2016, Sayı: 25, s. 167.

${ }^{30}$ Yusuf Devran, "Medya ve Terör Sorunsalı", Gümüşhane Üniversitesi İletişim Fakültesi Elektronik Dergisi, 2015, Cilt 3, Sayı 2, s. 87.

${ }^{31}$ Samet Zenginoğlu, agm, s. 170-171.
} 
getirmek için çalışmıştır. Bunu yaparken, terör olayı gerçekleşmeden

Güvenlik

Stratejileri

Y11: 14

Say1: 27 potansiyel düşmana karş1 önceden tedbirler almak ve bu tedbirleri alırken uygulayacağ 1 şiddeti meşru göstermek için çaba sarf etmiştir.

\subsection{Uluslararası Terörizmdeki Değişim}

Modern çağda bazı devletler terör örgütlerini kendi diplomatik ve stratejik hedeflerine ulaşmada kullanmaktadır. Ayrıca şiddet çok kolay uygulanmaya ve hatta bazen terör örgütleri uluslararası topluma eylemlerini başarı olarak göstermeye başlamıştır. Barışı tehdit eder hale gelen terör örgütleri, eylemlerini "fakir adamın" yaptığ olarak göstererek taraftar ve destek toplamaktadır. Bu açıdan bakarsak, terörizm yayılmaya başlamıştır. Kendilerini korumak adına terörist yöntemler kullanan devletler, terör sarmalını tırmandırmakta ve terör iyiden iyiye küreselleşmektedir. ${ }^{32}$

Uluslararası terörü etkileyen faktörler aşağıda sıralanmıştır:

- Teknolojinin ilerlemesi, gelişmesi ve hızı,

- Sicak çatışmalar, iç savaşlar ve bunun sonucunda oluşan kitlesel göçlerle eleman teminindeki kolaylık

- Siyasi şartlarda güncel olarak yaşanan değişimler,

- Soğuk Savaş'ın ardından teröre destek verenlerin sayılarındaki artış,

- Dünya genelindeki ekonomik hareketler ve yine dünya genelinde paranın dolaşımındaki rahatlık neticesinde terör örgütlerinin mali ihtiyaçlarının giderilmesi. ${ }^{33}$

\subsection{Terörün ve Terör Örgütü Elemanlarının Psikolojisi}

Genel olarak incelendiğinde, terör örgütü elemanlarının toplumsal düzene faydaları olmayan, yaşadığı ülkeye bir katkısı bulunmayan, ekonomik ve sosyal hayata herhangi bir destek sunmayan, kişisel sorunlar yaşayan, çaresizlik ve acizlik duygusu içinde olan, kötümser ve bulunduğu çevreden kurtulmak isteyen yapıda insanlar olduğu anlaşılmaktadır.

\footnotetext{
${ }^{32}$ Mesut Hakkı Caşın, age, s. 208.

${ }^{33}$ Mesut Hakkı Caşın, age, s. 208-210.
} 
Uluslararası Terörizmin Değişen Yapısı ve Terör Örgütlerinin

Sosyal Medyayı Kullanması: Suriye'de DAEŞ ve YPG Örneği

Ayrıca, terör örgütleri taraftarlarını ve elemanlarını ikna etmek adına toplumun bozuk olduğu ve düzelemeyeceği, baskı unsuru olarak şiddet kullanan devlete karşı şiddet uygulanması gerektiği, şiddetle ortadan kaldırılan devletin yeni düzeninde ve sisteminde adaletin olacağı, halkın Güvenlik Stratejileri bunu kuracağı ve terörizmin çözüm üretebileceği ana düşüncesini ortaya koymaktadır.

Terör örgütleri, örgüt içerisinde bir grup dinamiği ve hareketi yaratarak elemanlarını grubun ayrılmaz bir parçası haline getirir. Daha sonra kazanılacak elemanlar da bir şekilde güdülenir. Mesela sıcak diyalog kurma, ekonomik sıkıntısı olanlara maddi destek sağlama, ailesine bakılacağı sözü, devlet kurulmasıyla meslek sahibi olacaklarının söylenmesi, kişilere aileleri veya çevresi tarafindan bile verilmeyen değer bunun için kullanılan araçlardır. Örgütün amaçları dışında hiçbir şey düşünmemelerini sağlayarak algılamalarında sadece bunu düşünmeleri sağlanmıştır. Daha sonra elemanlar kesin inanç adamı haline getirilir. ${ }^{34}$ Militan kimliği ve kişiliği kazandırılır. Elemanlar militan kimliği kazandırılırken, bazı aşamalardan geçerler. Bu aşamalar şunlardır:

- Fikirlerin aşılanarak eleman ve sempatizan toplanmas1,

- Fikirlerle ilgili yayınların okutulması ve eğitim verilmesi,

- Eylemde kullanılacak malzemelerin ve silahların çaylakların onurlandırılması adına taşıttırılması,

- Eylem için gereken silah ve teçhizatın sağlanması (belki de eyleme özel),

- Eylemlerde ve örgüt elemanlarının konuşlandığı yerlerde gözcülük yaptırılması,

- Eylem öncesi ve esnasında silahlı koruma yaptırılması,

- Yazı yazma, bildiri dağıtma ve afiş asma gibi eylemlere karıştırma,

- Militan adaylarının yasal gösterilere iştirakinin sağlanması,

- Korsan gösterilerde, şiddet içeren toplumsal hareketlerde ve direnişlerde boy gösterilmesi,

\footnotetext{
${ }^{34}$ Mesut Hakkı Caşın, age, s. 361-664.
} 
- Uzmanlık gerektirmeyen, basit olarak görülebilen eylemlere ve çatışmalara yönlendirilmesi,

- Silahlı faaliyetlere iştirak ettirilmesi,

- Teröristlerin yapacağı eylemlerin planlanmasında fikirlerine başvurulmas $1 .{ }^{35}$

Teröristlerin ruhu, kitle psikolojisiyle kaybolmakta ve yok olmaktadır. Herkesin artık ortak bir amacı vardır. Şuursuz ve iradesizdirler. Neyi neden yaptığını bilmeden eylemlere katılabilirler. Teröristler, terörist grup içinden yapılan düşüncelerin aşılanmasına kendini teslim eder. Artık sürü haline gelmişlerdir. Değerlendirme yapma ve yargı ortadan kalkmış; şiddet eğilimli ve saldırgan hale gelmişlerdir. Tahammülsüz ve kural tanımazdırlar. ${ }^{36}$

Terörün psikolojisinin odak noktasında nefret vardır. Nefret; ötekileşmiş, mağdur ve güçsüz bırakıldığını düşünen bireyleri bir arada tutar. Onlara güçlü oldukları hissini verir ve diğerleri artık lanetlidir. Karşıdakiler şer eksenidir ve şiddet uygulanabilir. Mazlum ve mağdurluk psikolojisi sonucu öfke, nefrete; nefret, şiddete; şiddet ise örgütlü teröre dönüşebilir. "Ya benimlesin ya da karşımdasın" fanatizmi kişileri teröre yönlendirebilir. ${ }^{37}$

Terörün psikolojisindeki bu keskin yargılar ve ötekiye duyulan nefret, terörün ve terörizmin amaçlarıyla da birleştiğinde, şiddet artış1 kaçınılmaz hale gelir. Zaten terör örgütleri tarafindan yukarıda anlatılan aşamalar sonucunda robotlaşan kişinin şiddet uygulayan bir makineye dönüşmesi de kaçınılmaz hale gelir. Terörün psikolojisinin temelinde bulunan ve meydana gelmesinde etken olan nefretin ve fanatizmin ortadan kaldırılmasıyla terörün büyük ölçüde ortadan kalkacağı da aşikârdır.

${ }^{35}$ Necati Alkan, "Terör Örgütlerinin Gençliği Kazanmada Kullandığı Psikolojik Süreçler”, Türkiye'de Terörizm Dünü Bugünü, Gelişimi ve Alınması Gereken Tedbirler, Bildiriler, Ankara 10-11 Mayıs 2000, Türk Tarih Kurumu, Ankara, 2003, s. 162-172.

${ }^{36}$ Mesut Hakkı Caşın, age, s. 377.

${ }^{37}$ Kemal Sayar, "Terörün Psikolojisi", http://www.kemalsayar.com/KatagoriDetayTerorun-Psikolojisi-37.html (Erişim Tarihi: 23.02.2018). 
Uluslararası Terörizmin Değişen Yapısı ve Terör Örgütlerinin

Sosyal Medyayı Kullanması: Suriye'de DAEŞ ve YPG Örneği

\section{Terör Örgütlerinin Sosyal Medya Kullanımı}

Terör örgütleri, küreselleşmeyle ve dünyada teknolojinin gelişmesiyle birlikte bunun faydalarından yararlanma yoluna girmiştir. Böylelikle teknolojinin gücüyle ses getirici eylemlerini daha geniş kitlelere ulaştırma şansını yakalamış; ayrıca eleman kazanma açısından bakarsak, özellikle sosyal medyanın kullanılmasıyla gençleri daha fazla etkilemiştir. Çekilen dehşet ve propaganda görüntülerinin kitleler üzerinde etkisi çok fazla olmuştur. Yaptıkları eylemler sonucunda gazete ve dergilerin manșetlerine çıkmak; buralarda belli bir süre kalmak; kitleler üzerinde farkındalık yaratılmasında ve terör örgütlerinin amaç ve ideolojilerinin tanitılmasında büyük yer tutmuştur.

Yayıncılık ilkeleri doğrultusunda halkın en tabii hakk1 olan haber alma hakkını kullanmasını sağlayan medya, büyük ölçüde istemeyerek de olsa, bu propaganda faaliyetlerine alet olabilmektedir. Doğal olarak, medya kuruluşları hayatlarını devam ettirebilmek, gelir elde etmek ve aynı zamanda habercilik yapmak durumundadır. Bu medya kuruluşlarının ve şirketlerin varlığını sürdürmesi için mali kaynaklara ihtiyacı vardır. Haberlerinin veya yapılan programlarının takip edilmesi, çok izlenmesi, ayrıca gazete ve dergilerin baskı sayılarının artması ve çok satması bu kaynakları sağlamaktadır. Medya şirketleri izleyici ve okuyucu kitlesinin ilgisinin çekilmesiyle gelir elde etmektedir. Medya şirketleri, bunları terörle mücadeleye zarar vermeden gerçekleştirmeli; halkın haber alma ihtiyacının karşılanması ile devletin terörle mücadelesi arasında hassas bir denge oluşturmalıdır. Aslına bakarsak, terör örgütleri kendi reklamlarını medyayı kullanarak ve medya aracılığıyla yaparken; medya kuruluşları da bu terör eylemlerinden daha fazla izleyici çekebilmektedir.

Terör eylemleri, bundan en çok etkilenen kesimi, yani toplumu ilgilendirdiğinden, medya için çok fazla değer taşımaktadır. Bu haberler dijital, görsel, yazılı ve sosyal medyada verilmektedir. Özellikle son yıllarda Suriye'de DAEŞ terör örgütünün medyayı çok iyi kullandığını biliyoruz. Örgüt çektiği ve yayınladığı vahşet görüntüleri ile medyada çok fazla yer almaktadır. Teröristler ile medya kuruluşları karşılıklı olarak birbirlerinden faydalanmaktadır. 
58

Güvenlik

Stratejileri

Y11: 14

Say1: 27

Terör örgütleri medya vasıtası ile taleplerini iletme, kendilerini ifade etme ve farkındalık yaratma firsatı ele geçirirken; diğer taraftan medya haber elde etme firsatını yakalamaktadır. Bir terör organizasyonu olduğu için doğal olarak kürsüde kendini ifade edemeyen ve reklam yapma hakk1 olmayan terör örgütleri, medya aracıllğıyla bu firsatları yakalamayı başarmaktadır. Bu ilişki aslında her iki tarafın da çıkarına gibidir. Sunulan haberlerin bilinçli ve terör örgütlerinin propagandasına yol açmayacak şekilde dikkatlice yapılması, medyanın bu görevini yerine getirmesine olanak tanırken, aynı zamanda terörle mücadeleye de katkıda bulunur.

Terör örgütleri dikkat çekmek, kamuoyunda farkındalık yaratmak, devlet yetkilileri tarafindan tanınmak ve saygınlık ve meşruluk kazanmak ve aynı zamanda devlet veya hâlihazırdaki hükümetle iletişim kurmak ister. Tabii ki, daha önce de söylediğimiz gibi, halk üzerinde kaygı, korku, endişe yaratmayı ve gündemde kalmayı da amaçlar. Terör örgütler, medyada yer almakla, düşmanca mesajlarını karşısındaki güvenlik kuvvetlerine ve halka duyurma imkânı elde eder. Bunları neden yaptıklarını ve buradaki amaçlarını şöyle sıralayabiliriz:

- Propagandalarını yapmak ve hedefledikleri kitle üzerinde korku uyandirmak,

- Kitleleri amaç ve hedefleri yönünde seferber ederken bu amaçlarını ve hedeflerini tanıtmak,

- Güvenlik güçlerinin bazı uygulamalarının hukuka aykırı olduğunu göstererek halkın gözünden düşürmek,

- Sempati besleyenleri ve destekçilerini artırmak,

- Örgüt elemanlarını davalarına daha fazla çekmek, sadakat yaratmak ve onları cesaretlendirmek, ${ }^{38}$

- Örgüt içerisinde haberleşme sağlamak,

- Uluslararası arenada bilinirlilik sağlamak,

- Dış destek sağlamak.

${ }^{38}$ Hüseyin Kazan, agm, s. 117. 
Uluslararası Terörizmin Değişen Yapısı ve Terör Örgütlerinin Sosyal Medyayı Kullanması: Suriye'de DAEŞ ve YPG Örneği

Teröristler genel olarak eylem zamanlarını ve yerlerini medyanın kural ve mantı̆̆ını kullanarak seçer; yani medyanın kolay ulaşabileceği ve görüntü alabileceği yerleri seçmeye özen gösterir. Bunlar insanların çok kullandıkları mekânlar, popüler semtler ve kalabalık yerlerdir. Medya kuruluşları buralara yakın yerlerde olduklarından ya da buralara yakın yerlerde muhabirleri olduklarından kolay ulaşır. Mesela, İstanbul'da 1 Ocak 2017 gecesi DAEŞ tarafindan Reina gece kulübüne yapılan saldırı, böyle bir saldırıdır. Terör örgütleri, yazılı medyanın toplumu bilgilendirme ve olan olaylardan doğru bir şekilde haberdar etme sorumluluğu olduğu bilinciyle hareket eder. Medya, terör olaylarını görmezden gelemediği için bunları yayınlamaktadır. Ancak bu yayınlardan terör örgütlerinin yararlanmaması sağlanmalıdır. Medya kuruluşları ulusal ve uluslararası güvenliğe karşı sorumlulukla ve terörle mücadeleye zarar vermeden yayın yapmalıdır.

Terör örgütleri eylem yapmak için siyasi partilerin seçim öncesi propaganda dönemini, seçimleri, uluslararası toplantıları, spor karşılaşmalarını ve uluslararası organizasyonları seçmektedir; çünkü bu dönemde daha fazla medyada yer alma imkânına sahip olmaktadır; zaten medya da hazır orada beklemektedir. Terör haberleri, en fazla takip edilen haberler arasındadır. Bu duruma örnek olarak 10 Aralık 2016 günü Beşiktaş maçı sonrası stada yakın bir yerde olan patlamayı ve miting için Ankara Garı'na gelenlere karşı 10 Ekim 2015'te yapılan saldırıy verebiliriz. ${ }^{39}$

Tabii, bunun yanı sıra, terör örgütleri teröre uluslararası bir kimlik kazandırmak için turistlerin yoğun olduğu yerlerde eylem yapmak istemekte ve bunu yaparken de bazen yabancı teröristleri de kullanmaktadır. Mesela 2017 yılbaşı gecesi eğlence merkezi Reina'ya yapılan saldırıyı Özbekistan vatandaşı Abdulkadir Masharipov gerçekleştirmiştir ve bu eylemde 39 kişi hayatını kaybetmiştir. Bu saldırının planlayıcıları da, saldırıya yardım edenler de genel olarak Türk vatandaşı değildir. DAEŞ militanı olan terörist, emri Suriye'den

\footnotetext{
${ }^{39}$ Hüseyin Kazan, agm, s. 122.
}

Güvenlik Stratejileri Y11: 14

Say1: 27 
60

Güvenlik

Stratejileri

Y11: 14

Say1: 27

aldığını belirtmiştir. Buradaki örnekte anlaşıldığ 1 gibi, bu saldırı, İstanbul'un en ünlü eğlence mekânlarından biri, yine turistlerin yoğun gittiği, birçok kişinin bulunduğu yılbaşı gibi bir gün seçilerek yabancı bir terörist tarafından yine sınırların dışından, Suriye'den, alınan bir emirle gerçekleştirilmiştir. Bu, uluslararası terörizm şablonuna tam uyan bir saldırıdır. ${ }^{40}$ Yine 12 Ocak 2016 günü Alman turistlere yapılan ve 12 Alman turistin öldügü Sultanahmet saldırısı da bu kalıba uymaktadır. Saldırıy yapan Nabıl Fadı isimli bir yabancidır ve planlayanlar yine DAEŞ terör örgütü tarafindan Türkiye'ye gönderilen yabancılardır. Saldırıya maruz kalan kurbanlar Alman'dır ve yer İstanbul'un popüler turistik mekânlarından Sultanahmet Meydanı'dır. $\mathrm{Bu}$ göstergelerin hepsi, bu saldırının bir uluslararası terör faaliyeti olduğunun kanıtıdır. $\mathrm{Bu}$ göstergelerin hepsinin bir arada olmasına gerek yoktur; bazı özellikleri karşılaması saldırının uluslararası olduğunu kanıtlamaktadır. ${ }^{41}$

Medyada terörle ilgili kavramları kullanılırken dikkatli olunmal1; toplum içerisinde teröristlerin insani değerlerini ön plana çıkaracak yayınlardan ve başlarına konacak sıfatlardan halk arasında terörist olduklarını gizleyecek tabirlerden kaçınılmalıdır. Tabii ki, bu gibi tabirler, genel olarak destek veren ülkeler ya da terör örgütlerinden çıkarları olan kesimler tarafindan siklıkla kullanılmaktadır.

Bazı Batılı basın yayın organlarının, mesela BBC'nin 23 Ağustos 2016 tarihindeki haberinde PKK terör örgütünden bahsederken "Kürt asi grup" diye bahsetmiş olduğunu görmekteyiz. Aynı haberde, yine PKK'nın Suriye'deki uzantısı olan YPG'nin DAEŞ'a karşı en etkili bir güç olduğu ve bu gücün de Türk topçu birlikleri tarafından hedef alındığ 1 yazmaktadır. Bu gibi tabirler teröre destek vermekte; terör örgütlerini cesaretlendirmekte; aynı zamanda taraftar ve maddi destek kazandırmakta; ayrıca diğer terör örgütlerine de cesaret vermektedir.

40 "Reina Katliam Davası Başlıyor", https://www.ntv.com.tr/turkiye/reina-katliamidavasi-basliyor,8iI-5e1Bs0qr6u5xnS6fwQ (Erişim Tarihi: 19.12.2017).

41 "Sultanahmet saldırısında 1 kişiye tahliye", https://www.birgun.net/haber-detay/ sultanahmet -saldirisi-davasinda-1-kisiye-tahliye-191478.html (Erişim Tarihi: 19.12.2017). 
Uluslararası Terörizmin Değişen Yapısı ve Terör Örgütlerinin

Sosyal Medyayı Kullanması: Suriye'de DAEŞ ve YPG Örneği

"Senin teröristin-benim teröristim" ikilemi ya da "özgürlük savaşçıs1terörist ikilemi” tüm ülkeler için tehlikeli bir ikilemdir. ${ }^{42}$ Yine YPG'li kadın teröristleri DAEȘ'e karșı savașan kahramanlar olarak gösteren yabancı medya kuruluşları da vardır. ${ }^{43}$ Bazı basın-yayın organlarının, aynaya bakan kadın teröristlerin fotoğrafını basıp savaşçı olarak niteleyip insani değerlerini öne çıkararak ve onların kadınların eşitliği için savaştığını öne sürerek, toplumun gözünde teröristleri yolda gördüğümüz, komşumuz veya arkadaşlarımız gibi normal olduğunu gösterme çabaları vardır. ${ }^{44}$

Medya, aynı zamanda, devletler tarafindan da kullanılmaktadır. Devletler, medya vasıtasıyla, çözümlerin demokratik yollarla olabileceğini; teröristlerin yaptıkları eylemlerin yanlış olduğunu anlatabilmektedir. Yalan yanlış bilgilerle halk arasında endişe yaratmak isteyen terör örgütlerine hizmet eden fisıltı gazetelerinin emelleri ve dedikoduları, yine halka doğru bilgiler verilerek, boşa çıkarılabilir. Bunun yanı sıra, medyada yer alan terör haberleri, terörün verdiği zararları ve ülke üzerindeki olumsuz etkisi ön plana çıkararak, halkın teröre karşı daha fazla kenetlenmesini sağlayabilir. Toplumu teröre karşı bilinçlendirilebilir ve bu konuda eğitim verilebilir. ${ }^{45}$

Medya, terör örgütleri tarafindan etkin bir şekilde kullanılırsa, halk kendini günlük yaşamda huzursuz ve korunmasız hissedebilir. Devamlı terör saldırılarını yaşama korkusu, insanların psikolojisini bozabilir; günlük yaşamdan uzaklaştırabilir. Hatta bazen insanların toplu bulunduğu yerlerden uzaklaşma isteği; bir terör saldırısına maruz kalındığında neler yapılacağı veya bir saldırıdan nasıl kurtulunacağ uzun süre insanların zihnini meşgul edebilir. Terörden endişe duyan

\footnotetext{
42 "Turkey v Syria's Kurds v Islamic State", http://www.bbc.com/news/world-middleeast-33690060 (Erişim Tarihi: 20.12.2017).

43 "Meet the Brave Women Fighting ISIS In Syria", https://www.huffingtonpost.com/entry/ kurdish-women-fighting-isis_us_56e05e98e4b065e2e3d46569 (Erişim Tarihi: 21.12.2017).

44 "In pictures: PKK fighters prepare for battle with IS", http://www.bbc.com/news/ world-middle-east-33991464 (Erişim Tarihi: 20.12.2017).

${ }^{45}$ Hüseyin Kazan, agm, s. 128.
}

61

Güvenlik

Stratejileri

Y1l: 14

Sayı: 27 
62

Güvenlik

Stratejileri

Y11: 14

Say1: 27

insanların, otobüs beklerken veya yolda yürürken bir terör saldırıs1 anında kendilerine kaçacak yer aramayla ilgili devamlı zihninde bir fikir olması ve kendine kaçıp kurtulacağı bir yer araması, olayın boyutunun ne kadar tehlikeli olabileceğini gözler önüne sermektedir. Terör, kitlelerin psikolojisini bozabilmektedir.

Medyada güvenlik güçlerinin şehitleriyle ve yaralılarıyla ilgili verilen haberlerin aşırılığ 1 , halkta bir güvensizlik duygusu yaratabilir. Tartışma programlarında haritalar açılarak yapılan değerlendirmeler; teröristlerin neyi doğru, neyi yanlış yaptığına dair analizler; güvenlik güçlerinin zafiyetlerini ortaya koyduğu gibi, teröristlerin de daha sonraki eylemlerinde zafiyet gösterdikleri alanda artık yanlış yapmamalarına ve önlem almalarına yol açar; yani teröristler bir nevi eğitilir. $\mathrm{Bu}$ durum, ayrıca birbirleriyle rekabet halindeki terör örgütlerinin eylem yarışına girmelerine yol açmakla birlikte, misilleme yapmalarına da sebep olabilir. Daha küçük ve etkisiz terörist gruplar, medyada güvenlik güçlerinin stratejileri hakkında yapılan tartışmalar sonucu, teknik ve taktik detaylar hakkında bilgi sahibi olabilir. Rehine kurtarma operasyonlarının televizyonlar tarafindan naklen yayınlanması, teröristlerin güvenlik güçlerinin konumları, taktikleri ve teçhizatı hakkında bilgi sahibi olmasına sebebiyet verir; örgütün medya vasıtasıyla isteklerinin duyurulmasını sağlarken, halk üzerindeki etkisini de daha eylem sonuçlanmadan gösterebilir. Yayınlanan haberler esnasında, örgüt isimlerinin sık sık tekrarlanması, örgütün reklamının yapılmasını sağlayarak örgüt propagandası haline gelebilir. Bazen medya kuruluşları tarafindan terör örgütlerinin yöneticileriyle yapılan röportajlar, bu yöneticilerin imajlarını güçlendirirken, tehditkâr söylemleri de yine halkta korku uyandırabilir. Ayrıca ülkede yaşayan insanların kafasında güvenlik güçlerinin bulamadığı terör örgütü yöneticilerinin medya kuruluşları tarafindan kolayca bulunması, soru işareti uyandırır ve güvenlik güçlerine güveni azaltabilir. Medya kuruluşlarınca örgütün verdiği hasarın ve insan zayiatının abartılması, yine örgüte moral, taraftar ve güç katmaktadır. Terör haberlerinin daima ilk sırada yer alması, başka sorunu yokmuşçasına, ülkenin imajını bozduğu gibi, ekonomik olarak da zarar görmesine sebebiyet vermektedir. Terör olaylarının medyada sık sık yer alması, o ülkede 
Uluslararası Terörizmin Değişen Yapısı ve Terör Örgütlerinin Sosyal Medyayı Kullanması: Suriye'de DAEŞ ve YPG Örneği

yaşayan insanların olayı kanıksayarak tepkisiz kalmasına yol açabilmektedir. $\mathrm{Bu}$ da halkın devlete güvenini azaltarak devlete bağl1lığa zarar vermektedir. Terörist ölümlerine yer verilmesi de, teröristleri kahraman yapabilmekte; basının yoğun ilgisi, bu ölümleri şova dönüştürebilmektedir. "Birazdan", "Son Dakika" ve "Flaş" kodu ile verilen haberler, çok çabuk ilgi çekmektedir. Ayrıca çok araştırılmadan verilen haberler, terör örgütlerine moral ve güç vermektedir. Haberin heyecanıla veya izlenme oranlarının kaygısıyla muhabirlerin heyecanla ve panik içindeki ses tonuyla yaptıkları anonslar ve olay yerinden görüntüleri de içeren programlar toplumda infial yaratabilmektedir. ${ }^{46}$

En son 20 Ocak 2018 günü başlayan Afrin'e yönelik Zeytin Dalı Harekâtı'nda yine boy boy haritalar ekranlarda gösterilmesine rağmen; sahadaki muhabirlerin daha dikkatli olarak harekâtın geliştiği yerler ve Türk Silahlı Kuvvetleri'nin konuşlandığı yerler hakkında çok fazla bilgi vermediği; sadece halkın bilgilendirilmesi konusunda yayın yapıldığı gözlemlenmiştir.

Terör örgütleri, eğer kendilerini güçlü ve yenilmez gösterebilirse ve kamuoyu da buna inanırsa, devletin meşruluğu sorgulanır hale gelir; aynı zamanda kamuoyu, hükümetlere bask1 yaparak, terör örgütüyle masaya oturulmasını ve müzakere sağlanmasını sağlayabilir. "Artık anlaşmaktan başka bir çare kalmamıştır" izlenimi yaratılarak, siyasi iktidar, terör örgütüyle dolaylı da olsa görüssebilir. ${ }^{47}$ Medyada terör örgütleri tarafindan yapılan propagandalar sonucu, bundan etkilenen, kendini güçsüz ve çaresiz hisseden siyasi iktidar, terörü bitirmek adına terör örgütleri ile görüşme çabası içine girebilir.

Türkiye'de medya ve terör konusunun tartışılması, kurbanların dakikalarca televizyonlarda gösterilmesi sebebiyle, 13 Mart 1999 Mavi Çarşı ve 20 Kasım 2003 HSBC saldırıları sonrasında yoğun şekilde başlamış; terör haberlerinin nasıl halka verilmesi üzerine tartışmalar

\footnotetext{
${ }^{46}$ Hüseyin Kazan, agm, s. 132.

${ }^{47}$ Yusuf Devran, agm, s. 89.
} 

yapılmıştır. $\mathrm{Bu}$ görüntülerin terör örgütünün amaçlarına hizmet ettiği kanaati doğmuştur. ${ }^{48}$

\section{Suriye'de Terör Örgütlerinin Medyayı Kullanımı}

Tanımlamak gerekirse, propaganda; bir öğreti, düşünce veya inancı başkalarına tanıtmak, benimsetmek ya yaymak amacıyla söz, yazı, v.b. yollarla gerçekleştirilen çalışma şeklinde tanımlanabilir. ${ }^{49}$ Araştırmacılar propagandayı klasik ve modern olarak ikiye ayırmaktadır. Klasik propaganda, bireyin tavır ve davranışını değiştirmeye çalışırken; modern propaganda bireyin tavır ve davranışını değiştirmeyle birlikte aktif olarak süreçlere katılmasını sağlamak ve bireyde tepki ve inanç oluşturmayı hedeflemektedir. Propagandacı, semboller kullanabilir ve bazı verileri çarpıtıp insanların buna inanmasını sağlayabilir. Sıkça söylenen kelimelerle insanların bu kelimeleri iyice öğrenmesini mümkün k1labilir. Propaganda yapılırken; dost ve düşman oluşturulur, seçiminizi propagandayı yapan kimsenin dost gördüğüne göre kullanmanız istenir. Vatan, bayrak ve ahlak gibi anlayışlar üzerinde çoklukla durulur. ${ }^{50}$ DEAŞ'ın da Suriye'de bu sayılanları etkin olarak kullandığını görmekteyiz. Dinî sembollerin kullanması; dinin çarpıtarak kullanılması; kendisinden olmayanın, Müslüman veya Hıristiyan ayırt edilmeksizin, ötekileştirilmesi ve düşman görülmesi bunlara örnek olarak verilebilir.

Geleneksel medyanın daha fazla kontrol edilebilir ve sansürlenebilir olması, yayın yasağı konabilmesi sebebiyle, daha kolaydır. Terör örgütlerinin bu nedenle sosyal medya üzerinde daha fazla durduğu açıktır. Geleneksel medya, terör örgütü propagandalarına karşı, genel anlamda, hükümetler tarafindan kontrol altına alınabilmektedir. Ülkelerinde yaşanan terör olaylarında, halkı dehşete ve umutsuzluğa itmemek adına, hükümetler yayın yasağı getirebilinmektedir. $\mathrm{Bu}$ şekilde, hem olayın güvenlik kuvvetlerince daha iyi araştırılmasına

${ }^{48}$ Yusuf Devran, agm, s. 86.

${ }^{49}$ Türk Dil Kurumu, http://www.tdk.gov.tr/index.php?option=com_bts\&arama= kelime\& guid=TDK.GTS.5a31a6b0052e38.79567432 (Erişim Tarihi: 29.12.2017).

${ }^{50}$ Erdem Taşdemir, "Sosyal Medya'da Terör Propagandası: Deaş Örneği”, 2017, Gümüşhane Üniversitesi İletişim Fakültesi Elektronik Dergisi, 2017,s. 728-731. 
Uluslararası Terörizmin Değişen Yapısı ve Terör Örgütlerinin

Sosyal Medyayı Kullanması: Suriye'de DAEŞ ve YPG Örneği

imkân tanınmakta; hem de eylemin halk üzerinde daha az etkisinin olması sağlanabilmektedir.

\subsection{Sosyal Medya}

Sosyal medya herkesin rahatlıkla katılımını, katkı yapmasını ve geri bildirimde bulunmasını sağladığından, medya ve kullanıcıları arasında kesin çizgi yoktur; erişebilirlik yönüyle hiçbir sınırlama bulunmamaktadır; çift yönlü olarak sohbet edilebilir; gruplar kurulup topluluklar hızla oluşturulabilir. Kullanıcılar, kendi ilgilendikleri konulara ve alanlarına göre sosyal ağlarını kurabilir; bazı konu ve kapsamlara katkı sağlayabilir; olaylara hızlıca tepki verilebilir. ${ }^{51}$ Sosyal medya büyük kitlelere kolaylıkla ulaşabilmekte; kitlelerin davranışlarını etkileyebilmekte duygularını değiştirebilmektedir. Bunlar, olumlu yönde de olabilir; olumsuz yönde de olabilir. ${ }^{52}$ İnternet ve sosyal medya kullanımı, birçok yönden terör örgütleri için uygun bir zemin oluşturur. Terör örgütleri ve elemanları açısından bakarsak, sosyal medyanın kullanılmasının en önemli nedenleri şunlardır: ${ }^{53}$

- bu kanallara kolay erişim,

- hükümet kontrolünün, sansürün, düzenlemenin bu mecralar üzerinde az olması veya hiç olmaması,

- olanaklar dahilinde dünya geneline yaygın olması, büyük bir dinleyici ve izleyici kitlesi,

- iletişimin gizliliği,

- bilginin kullanıcılar arasında hızlı akışı,

- web varlığının bakımının ve gelişiminin ucuz olması,

- multimedya ortami,

\footnotetext{
${ }^{51}$ Kristina Lerman, Social Information Processing in News Aggregation, https://pdfs.semanticscholar.org/2112/386f02791ff2074a33a341dd1e523d6e6a97.pdf (Erişim Tarihi: 02.01.2018).

${ }^{52}$ Ali Aslan, Türkiye'de Medya-Toplum İlişkisi Ve Medyanın Profesyonellik Etiği Üzerine Sosyolojik Bir Değerlendirme, Akademik Bakış, 2005, Sayı: 5, s. 10-11.

${ }^{53}$ Gabriel Weimann, "Special Report, How Modern Terrorism Uses the Internet", United States Institute of Peace, Washington, 2004, s. 3.
} 
66

Güvenlik

Stratejileri

Y11: 14

Say1: 27

- geleneksel iletişim araçlarında içeriği oluşturabilme.

Teröristler interneti

- Psikolojik savaş,

- farkındalık yaratma ve propaganda,

- bilgi ve veri toplama,

- yardım ve bağış toplama,

- örgüte eleman temin etme ve seferberlik,

- ağ oluşturma,

- gerektiğinde bilgi paylaşımı,

- yapacaği eylemleri planlama ve bu eylemlerin koordinasyonu amaciyla kullanmaktadır. ${ }^{54}$

Sosyal medyanın Suriye'deki terör örgütlerince etkin olarak kullanıldığ 1 aşikârdır. Bu, örgütler için daha az maliyetli ve daha az kontrol edilebilirdir. Özellikle DEAŞ ve YPG terör örgütleri Suriye'de sosyal medyayı etkin olarak kullanmaktadır.

\subsection{DAEŞ Terör Örgütü}

Suriye'de DAEŞ terör örgütünü incelediğimizde, örgütün hem resmî, hem de gayriresmî sayfaları kullanıp çoğunlukla da cihat kelimesini ön plana çıkardığı görülmektedir. Örgüt Youtube, Twitter, bloglar, mesajlaşma sistemleri ve çok sayıda başka platformu kullanarak hem propagandasını yapmış; hem de gerçekleştirdiği şiddet eylemlerini sergilemiştir. Örgüt, böylece, istediği konuyu ön plana çıkarmıştır. Taraftarlarını büyük ölçüde başarıyla harekete geçirebilmektedir.

DAEŞ terör örgütü, kendisine ait sunucular yerine ücretsiz ve herkese açik depolama hizmetlerinden faydalanmaktadır. ${ }^{55}$ Çektiği infaz görüntüleri vasıtasıyla korku ve endişe yaratmaktadır. Örnek olarak, Halep'in Hanat Assan köyünde çektiği infaz görüntülerini

${ }^{54}$ Gabriel Weimann, agm, s. 5-10.

${ }^{55}$ Emin Salhi ve Yenal Göksun, "Deaş'ın Medya Stratejisi”, SATEV Raporu, https://setav.org/assets/uploads/2018/01/98.-DAES\%CC\%A7-tamrapor.pdf (Erişim Tarihi: 12.02.2018). 
Uluslararası Terörizmin Değişen Yapısı ve Terör Örgütlerinin

Sosyal Medyayı Kullanması: Suriye'de DAEŞ ve YPG Örneği

Youtube'da yayımlayarak, Suriye'de halk arasında korku salmak istemiştir. $\mathrm{Bu}$, sosyal medya kullanımına verilebilecek örneklerden sadece biridir. ${ }^{56}$ Terör örgütü bunun gibi birçok video yayınlamıştır.

DAEŞ, sosyal medyaya çok hâkim bir örgüttür ve sosyal medyayı etkin olarak kullanmaktadır. Bu terör örgütü, yaptı̆g 1 propagandalar Güvenlik Stratejileri

Y11: 14 sonucu, yabancı savaşçıları, göçmenleri, Batı ülkelerinde yaşayan insanları DAEŞ adına terör eylemi yapabilir hale sokabilmektedir. Sosyal medya sayesinde örgüt kendi içine birçok yabancı teröristi çekebilmiştir. Yaptığı propaganda faaliyetleri ile üyelerini özellikle Müslümanlar arasında model hale getirerek eleman kazanmıştır. ${ }^{57}$

DAEŞ propagandasının ana mesajı, sözde hilafet yapısı altında Müslümanların yaşayabileceği bir ülke vaadidir. Örgüt, propagandalarında siyasi hedeflerini, dinî hedeflerini, sosyal hususları ve kendisinin yenilmez olduğunu anlatır. DAEŞ internet üzerinden iki adet dergi yayınlamaktadır. Bunlardan birincisi, İngilizce hazırlanan "Dabiq"dır ki, bu dergi örgüte ait "Al Hayat" Medya tarafindan hazırlanmaktadır. Diğeri ise Türkçe hazırlanan "Konstantiniyye" dergisidir. ${ }^{58}$ Buradan da anlaşılabileceği gibi, Türkçe hazırlanan dergiyle öncelikle Türkiye'den, hatta Türk Cumhuriyetlerinden ve Kafkasya, Balkanlar ve Rusya içerisinde yaşayan Türk asıllı halklardan eleman devşirmek istediği açıktır.

DEAŞ'ın propaganda üretmek ve dağıtmak için medya ofisleri vardır. "Al-Furqan" ve "Al-I'tisaam" ajansları Arapça filmler yapmaktadır. "Al-Hayat" Medya Merkezi, Batılılar için film ve yayınlardan sorumludur. "Al-Ajnad" ise dinle ilgili yayınlar yapmaktadır. Örgüt "İslam Devleti" ve "İslami Hilafeti”nin toprakları olarak adlandırdığı alanda propaganda faaliyeti sürdüren "al-Bayan" adlı bir

\footnotetext{
${ }^{56}$ Sabah İnternet Sayfas1, "Suriye'de Tüyler Ürperten İnfaz", https://www.sabah.com.tr/ webtv/dunya/suriyede-tuyler-urperten-infaz (Erişim Tarihi: 12.02.2018).

${ }^{57}$ Erdem Taşdemir, agm, s. 739.

58 "Terör Örgütleri ve Propaganda: Daeş Terör Örgütü Örnek Olay İncelemesi”, 21 YY Türkiye Enstitüsü, http://www.21yyte.org/tr/arastirma/orta-dogu-ve-afrika-arastirmalarimerkezi/2017/05/10/8627/teror-orgutleri-ve-propaganda-daes-teror-orgutu-ornek-olayincelemesi (Erişim Tarihi: 03.01.2018).
} 
68

Güvenlik

Stratejileri

Y11: 14

Say1: 27

radyo istasyonuna ve Twitter'da ilgili haberleri veren ajansa sahiptir. Her vilayette, videoların çekimi ve dağıtımı için yerel medya ofisleri kurulmuştur. $\mathrm{Bu}$ medya ofisleri bölgede raporlar hazırlamaktan sorumludur. $^{59}$

Örgüt elemanları, Twitter üzerinden her dilde konuşarak yoğun propaganda faaliyeti yürütür. Facebook'ta ise örgüt tarafindan üretilen materyaller dağıtılır; mesela bomba tarifi, silah bakımı, eğitim propaganda ve aşırı radikal mesajlar, uzaktan keşif kaynağı bilgileri yazılır. Youtube ise yine propaganda ve vahşet görüntülerini yaymak için kullanılır. ${ }^{60}$ Yani DEAŞ terör örgütü, sosyal medya aracıllı̆̆ ile sesini duyurmakta ve insanları etkilemekte başarılı görünmektedir. Güvenlik birimlerince bu görüntülerin incelenmesi ve değerlendirilmesi ile örgüt hakkında bilgi toplanması ve yapılacak operasyonlar için örgüt elemanlarının yerlerinin tespiti önem arz etmektedir.

\subsection{YPG Terör Örgütü}

Yine DAEŞ gibi, YPG de aynı şekilde medyayı propaganda amaçlı ve eleman temini için kullanmaktadır. Özellikle son zamanlarda kendisine silah desteği veren ülkelerden aldığı silahları ve düzen içinde gösterdiği terörist unsurları sergileyerek medya vasıtasıyla dünyaya mesaj vermektedir. Hatta bazı eski görüntüleri veya başka yayın organlarından temin ettiği yalan-yanlış haberleri yeniymiş gibi göstererek destekçilerine moral vermek ve örgüte bağlll l̆ğ sürdürmek istemektedir. Yemen'de çekilmiş bir yanan zırhlı aracın görüntüsünün, daha önce Sputnik'te yayınlanmış yanan tank görüntüsünün, Manisa'da gıda zehirlenmesi sonucu hastaneye kaldırılan askerin ve Suriyeli muhalifler tarafindan ele geçirilen Hizbullah timinin sanki Türkiye'nin 2018 Ocak ayında Suriye'de başlattığı Zeytin Dalı Harekâtı'nda yaralanmış gibi

${ }^{59}$ Adam Hoffman, “The Islamic State's Use of Social Media: Terrorism's Siren Song in the Digital Age", http://daatsolutions.co/inss/wp-content/uploads/systemfiles/The\%20Islamic $\% 20$ State $\%$ E2\%80\%99s $\% 20$ Use $\% 20$ of $\% 20$ Social $\% 20$ Media\%20Terrorism\%E2\%80\%99s $\% 20$ Siren $\% 20$ Song\%20in\%20the\%20Digital $\% 20$ Age $\% 20 \% 20$ Adam $\% 20$ Hoffman.pdf (Erişim Tarihi: 02.02.2018).

${ }^{60}$ Erdem Taşdemir, agm, s. 740-741. 
Uluslararası Terörizmin Değişen Yapısı ve Terör Örgütlerinin

Sosyal Medyayı Kullanması: Suriye'de DAEŞ ve YPG Örneği

gösterilmesi bu konulara örnektir. ${ }^{61}$ Aynı DAEŞ gibi sosyal medyayı da etkin olarak kullanan PKK'nın Suriye'de kolu YPG, uluslararası medyaya da röportajlar ve görüntüler vererek kendisini DAEŞ'le mücadelede en etkin unsur olarak göstermekte; bu yolla da Batılı ülkelerin desteğini almaktadır.

YPG'nin özellikle PKK ile yakın ilişkisi ve bu örgütün Suriye kolu olmas1, bunun yanında iki örgütün birbiriyle iç içe geçmiş eylemleri ve yönetici kadrolarının aynı olması; propaganda faaliyetlerinin de tek elden ve tek bir merkezden yürütülmesini sağlamaktadır. PKK'nın bu konuda edindiği tecrübelerin ve destek sağlayan ülkelerin sayesinde, medyayı etkin kullanmak istemektedir.

\section{Sonuç}

Uluslararası terörizm, küreselleşme ve Soğuk Savaş'ın bitimi sonrasında 11 Eylül saldırılarıyla birlikte vekâleten savaşların yönetildiği bir dünyada, devletlerin en fazla üzerinde durduğu konu haline gelmiştir. Soğuk Savaş döneminde daha kontrollü olan terörizm, artık kontrolden çıkmış, terörün ve terör örgütlerin tanımı artık daha karmaşık bir hal almıştır. Bir ülke için terör örgütü olan bir örgüt, başka bir ülke tarafindan terör örgütü olarak nitelenmemekte; hatta beraber çalış1abilecek gruplar olarak değerlendirilmektedir. Bunun en yakın örneğini, Suriye'de YPG-PKK terör örgütleri üzerinden görebilmekteyiz. Türkiye Cumhuriyeti'nin güney sınırlarında tehdit olan bu örgüt, ABD tarafından Suriye'de DEAŞ terör örgütü ile aynı zamanda Suriye rejimi ile mücadelede bir ortak olarak görülmekte ve bu örgüte destek verilmekte, eğitim, silah ve teçhizat yardımı yapılmaktadır. Aralarında en modern silah ve teçhizatın da bulunduğu bu yardımların, Türkiye'nin terörle mücadelesinde olumsuz etki yapacağı gayet açıktır. En son Türk Silahlı Kuvvetleri tarafindan Suriye'nin kuzeyinde icra edilen Zeytin Dağı Harekâtı'nda YPG-PKK terör örgütü bu silahları kullanmıştır. Önemli bir miktarda silah da mağaralarda, sığınaklarda, yeraltına inşa edilen

\footnotetext{
61 “4 Yalan 4 Gerçek”, https://www.yenisafak.com/gundem/4-yalan-4-gercek-3026136 (Erişim Tarihi: 24.01.2018).
} 
70

Güvenlik

Stratejileri

Y11: 14

Say1: 27

cephaneliklerde ve silah depolarında ele geçirilmiştir.

Terör örgütlerinin başka devletler tarafindan fonlanmasının, destek veya eğitim verilmesinin ne kadar yanlış politikalar içerdiği ABD’ye yapılan 11 Eylül saldırılarında kendisini göstermiştir. Saldırıyı yapan El-Kaide örgütü, Sovyetler Birliği'ne karşı ABD tarafindan desteklenen bir örgüttür. Aynı hatayı Suriye'de PKK-YPG'ye destek vererek yapan ABD'nin gelecekte bu destekten zarar görebileceğini; verdiği silahların bu örgüt tarafindan kendisine döndürülebileceğini ya da bu silahların başka terör örgütlerinin eline geçmesiyle de yine zarar görebileceğini tahmin etmek çok zor değildir. Bu nedenle, daha önceki 11 Eylül saldırılarından ders alan ABD'nin masum insanların zarar görmesini engellemek adına zaman kaybetmeden Suriye'de verdiği silahları geri alması ve desteğini kesmesi gerekmektedir.

Terörün uluslararası hale gelmesi, artık hiçbir devletin kendi topraklarında emniyet içerisinde olmadığı anlamına gelmektedir. Artık teröristler birkaç değişik ülkeden gelmekte; eylemleri sınırları aşmakta; değişik ülkeler tarafindan desteklenmekte; dünyanın her yerinde etkisi olabilecek eylemlerin altına imza atmakta ve tüm dünyada korku ve endişeye yol açmaktadır. Teröristler, aynı zamanda küreselleşmeyle ve teknolojik gelişmelerle, propaganda malzemesi olarak medyayı etkin kullanmakta; teknolojik gelişmeleri özellikle eylem biçimlerinde, eylemin hazırlanmasında, planlanmasında ve icrasında kullanmaktadır. Örnek olarak, terör örgütlerinin elde ettiği silahlar daha teknolojiktir; örgütler eylem öncesi istihbarat toplamaları esnasında daha gelişmiş araçlardan faydalanmakta; çok daha gelişmiş iletişim vasıtalarını ve gözetleme vasıtalarını ve ayrıca eleman teminlerinde yine gelişmiş medya araçlarını etkin bir şekilde kullanmaktadır.

Ancak tabii ki teknolojik gelişmelerden ve küreselleşmeden en çok faydalananlar arasında terörle mücadele kapsamında faaliyet yürüten güvenlik güçleri de vardır. Özellikle devletlerin propagandalarında medyayı kullanması çok etkindir. Vatandaşlarını zamanında ve doğru bir şekilde bilgilendiren ülkeler, terör örgütünün eleman temini ve halkta yılgınlık korku yaratma hedeflerinin engellenmesini sağlamıştır. Daha modern silah ve teçhizatla donatılmış güvenlik güçlerinin terörle mücadelede daha başarılı olacağı ve daha az insan kaybı ile görevini 
Uluslararası Terörizmin Değişen Yapısı ve Terör Örgütlerinin

Sosyal Medyayı Kullanması: Suriye'de DAEŞ ve YPG Örneği

sürdüreceği açıktır. Halkın terör örgütlerinden uzaklaşması ve desteğini çekmesi, en önemli konudur. Devletlerin, terörle mücadelesini önce kendi vatandaşlarına, daha sonra da diğer ülkelere, oluşturacağı politikalar vasıtasıyla ve özellikle de uluslararası platformda iyi bir şekilde anlatması gereklidir. Devletler, terör örgütleri arasında ayrım yapmaksızın, diğer ülkelerin yaptığı terörle mücadelelere destek vermeli ve bu konuda adımlar atmalıdır.

Uluslararası terörün yeni yüzüne dikkat çekersek, bu, artık terörün global hale gelmesidir. Bununla ilgili olarak atılması gereken adımlar şunlardır:

- Terör unsurlarının tüm devletlerden eleman teminini engellemek için devletlerarası bir eylem planının hazırlanmasının sağlanması, sağlanmas1,

- Terörle mücadelede BM'nin etkin olarak rol oynamasının

- Terörle mücadelede terör örgütleri arasında ayrımın ortadan kaldırılması ve devletler arasında bu konuda geniş bir mutabakatın sağlanması,

- Uluslararası terörle mücadelede toprakları üzerinde tam kontrol sağlayamayan ülkelerin terörle mücadelesinde BM öncülügünde destek verilmesi, gerekirse çok uluslu güçlerle bu mücadelenin sürdürülmesinin sağlanması ve bu konuda BM kararlarının alınması,

- Devletlerin sinırlarına komşu devletlerden gelecek olan saldırılara karşı diğer komşu devletten hemen müdahale etmesini istemesi, eğer bu devlet bir iç savaş içerisindeyse veya topraklarının tamamına hâkim değilse bu devlete ve BM Güvenlik Konseyi'ne haber vererek BM Antlaşmas1 51. maddesi gereği derhal müdahale etmesi,

- Medyanın etkin kullanılması,

- Herkesin mutabık kalacağı bir terör ve terörizm tanımının yapilmas1,

- Ülkelerin vatandaşlarına kendilerini rahatça ifade etme imkânı vermesi ve tüm vatandaşlarına eşit olarak davranması.

Terör örgütlerinin ve devletlerin medya ve sosyal medyay kullanması konusuna gelirsek, devletler medyayı etkin kullanarak halkına doğru ve zamanında bilgi vermeli; medya kuruluşları sorumluluk

Güvenlik

Stratejileri

Y11: 14

Say1: 27 
72 duygusuyla ve meslek etiğiyle haber vermelidir. Terör eylemlerinin

Güvenlik

Stratejileri

Y1l: 14

Say1: 27 ardından soruşturmanın daha iyi yürütülmesi ve örgütlerin yapacağı propagandaların engellenmesi için kısa bir zaman bile olsa yayın yasağı getirilmeli, ancak süratle kaldırılmalıdır. Medyada terörün ülkeye verdiği zararlar halka anlatılmalıdır. Bir eylemin ardından muhabirlerin diğer kanallarla haber yarışına girerek yapılan eylemi değişik şekillerde anlatması ve hatta ekranda sanki rol yaparcasına koşarak ve heyecanlı bir ses tonu izleyiciye duyurması, ülkelerin terörle mücadelesine hiçbir katkı sağlamayacağı gibi zararının büyük olacağı açıktır. Operasyonlar esnasında terör örgütlerini bilgilendirici ve eğitici yayınlardan kaçınılmalıdır. Suriye örneği, terör örgütlerinin sosyal medyay1 kullanması açısından en iyi örnektir. Medyanın kullanılması vasıtasıyla DAEŞ terör örgütü, Avrupa ülkelerinde eylem yapabilmekte ve buradan eleman temin edebilmektedir.

\section{Summary}

The end of Cold War and disintegration of the Soviet Union had created a power gap, which eventually stipulated war on terrorism, especially after the terrorist attacks on 9/11. This study evaluates international security threats and international terrorism. The study also investigates how these terrorist organizations are associated with social and electronic media and how they use these two media types. The nature of international terrorism has changed since the end of Cold Ward. In this change, social media's impact has been particularly considerable.

In the past, terrorist organizations preferred narrow-scoped acts. Nowadays, they are inclined to be more complicated, cross-border, and adaptive international acts of terrorism. The term terrorism has many definitions. Although these definitions look similar, they also have many diverse aspects. However, all definitions have some common points that they all include descriptions of violence, subversion, and disturbance.

Security threats during post-Cold War period have also been reshaped due to globalization. In fact, in this period, socio-economic issues prevailed as security threats. Nevertheless, threats like terrorism and organized crime have also been globally present. 
Uluslararası Terörizmin Değişen Yapısı ve Terör Örgütlerinin

Sosyal Medyayı Kullanması: Suriye'de DAEŞ ve YPG Örneği

All international actors participated in war against terrorism, because security perceptions have been updated. This is particularly due to the changing nature of border crossing, internationalization of terrorist organizations, multinational identity of these organizations, involvement of many countries in terrorism issues, and increasing number of transnational crimes. Furthermore, it is equally important to emphasize that all these problems are now concerned with many nation-states, not a single one as it was before.

Transnational terrorism makes international impacts, which pave the way for international terrorism. Terrorism becomes international, only if it targets foreign nationals. Terrorism is also internationalized when it is supported by foreign governments. In addition, terrorist activities are considered international when they violate international laws, create everlasting conflicts among nations, and threaten international peace and security.

In some occasions, international terrorism and organized crime are intermingled and even confused. It is clear that both of them damage relations between states and international security. As a concept, "organized crime" was first used after the First World War in the USA. After the Second World War, it was replaced with the term "mafia". These crime organizations began to commit crimes, such as drug trafficking, smuggling of nuclear materials, arms, and forgery.

As current studies suggest, members of terrorist organizations have some common characteristics. They generally have personal problems. They suffer from desperation and pessimism. Terrorist organizations create group dynamics in order to make these desperate members as indispensible components of a team. Further, recruits are also motivated in the same manner. In doing so, these members only think of the objectives of terrorist organizations.

Terrorist organizations began to benefit from globalization and fruits of advanced technology. Therefore, they gained capability to access larger audiences thanks to their sensational terror acts. Furthermore, in terms of recruitment, active use of social media brings benefit to such organizations in order to influence youngsters. These

Güvenlik Stratejileri

Y11: 14

Say1: 27 
74

Güvenlik

Stratejileri

Y1l: 14

Say1: 27

images of terror and propaganda have considerable impact on masses.

Media companies need financial sources to survive. This financial power of media depends mostly on its ratings and advertisements. However, in some cases terrorist organizations might make use of media indirectly. News about terrorism attracts much attention; therefore, the names of terrorist organizations and terrorists themselves become popular. Terrorist organizations may also use media directly. Their broadcasting in the media might make people feel uncomfortable and even unprotected. Constant fear of terrorist attacks might create depression in society and isolate people from everyday life.

Social media is open for everyone. It is open for everyone's contribution and feedback. Therefore, there are no certain lines between social media users. There are no limitations concerning accessibility. For this reason, terrorist organizations also benefit from these advantages of social media. For example, members of such organizations communicate each other easily. They recruit new members through social media. More importantly, they hide facts and even manipulate them. This creates disinformation and consequently confusion and fear among society. In order to minimize impacts of terrorist organizations on social media, it is necessary to establish freedom of communication by governments. Finally, these issues suggest that war against terrorism requires United Nations' active participation and a consensus over an action plan between states in the future.

\section{Kaynakça}

Kitaplar

CAŞıN, Mesut Hakkı, Uluslararası Terörizm, Nobel Yayın Dağıtım, Ankara, 2008.

LAQUEUR, Walter, The New Terrorism, Oxford University Press, Oxford, 1999.

SNOW, Donald M., Terrorism: The Changing Global Threat, Cases in International Relation, Longman, New York, 2012. 
Uluslararası Terörizmin Değişen Yapısı ve Terör Örgütlerinin

Sosyal Medyayı Kullanması: Suriye'de DAEŞ ve YPG Örneği

\section{Makaleler}

ASLAN, Ali, "Türkiye'de Medya-Toplum İlişkisi ve Medyanın Profesyonellik Etiği Üzerine Sosyolojik Bir Değerlendirme", Akademik Bakış, 2005,Sayı 5, 1-13.

BOZDEMIR, Mevlüt, "Terör (mü) ve Terörizm (mi)?”, S.B.F. Basım Yayım Yüksek Okulu Yıllı̆̆g, Ankara, 1982, cilt 6, 523-530.

DEVRAN, Yusuf, "Medya ve Terör Sorunsalı", Gümüşhane Üniversitesi İletișim Fakültesi Elektronik Dergisi, 2015, Cilt 3, Sayı 2, 84-95.

ERGIL, Doğu, "Uluslararası Terörizm", Ankara Üniversitesi Siyasal Bilgiler Fakültesi Dergisi, 1992, Cilt: 47, Say1: 3, 139-143.

KANAT, Selim vd., "İnsani Güvenlik ve Terörizm ile Mücadele", Süleyman Demirel Üniversitesi İktisadi ve İdari Bilimler Fakültesi Dergisi, 2016, Cilt: 21, 567-588.

KAZAN, Hüseyin, "Terör Medya İlişkisi ve Medya Terör Haberciliği”, Güvenlik Stratejileri Dergisi, 2016, Y11: 13, Say1 24, 109-147.

MEHMEDLİ, Elșen, "Güvenlik Tehditleri ve Uluslararası Terörizm", Süleyman Demirel Üniversitesi Sosyal Bilimler Enstitüsü Dergisi, 2016, Say1: CİEP Özel Sayıs1, 986-995.

SEMERCIOĞLU, Harun, "Uluslararası Terörizmde Küresel İşbirliği: Bir Ütopya", Hacettepe Üniversitesi İktisadi ve İdari Bilimler Fakültesi Dergisi, 2016,Cilt: 34, Say1: 2, 97-114.

TAŞDEMIR, Erdem, "Sosyal Medya'da Terör Propagandası: Deaş Örneği”, Gümüsshane Üniversitesi İletişsim Fakültesi Elektronik Dergisi, 2017, Cilt: 5 Say1: 2, 726-752.

ÖZ YILDIZ, Seda, "Makarenko'nun "Kara Delik Sendromu” Teorisi ve Terörizm Finansmanında Sinıraşan Organize Suçlar", Güvenlik Stratejileri Dergisi, 2017, Y11: 13, Say1: 25, 27-64.

ZENGINOĞLU, Samet, "Uluslararası Terörizm ve Avrupa Birliği", Süleyman Demirel Ünversitesi Sosyal Bilimler Enstitüsü Dergisi, 2016, Say1: 25, 157-178.

\section{Bildiriler}

ALKAN, Necati, "Terör Örgütlerinin Gençliği Kazanmada Kullandığ1 Psikolojik Süreçler", Türkiye'de Terörizm Dünü Bugünü, Gelişimi ve Alınması Gereken Tedbirler, Bildiriler, Ankara 10-11 Mayıs 2000, Türk Tarih Kurumu, Ankara, 2003. 
Atahan Birol KARTAL

76

Güvenlik

Stratejileri

Y11: 14

Say1: 27

BAŞEREN, Sertaç, "Kavramsal Özellikleri ile Terörizm”, Küresel Terörizm ve Uluslararası İşbirliği Sempozyumu, Genelkurmay Basımevi, Ankara, 2006.

\section{Raporlar}

SALHI, Emin ve Göksun, Yenal, "Deaş'ın Medya Stratejisi”, SATEV Raporu, https://setav.org/assets/uploads/2018/01/98.-DAES\%CC\%A7tamrapor.pdf, (Erişim Tarihi: 12.02.2018).

"Terör Örgütleri ve Propaganda: Daeş Terör Örgütü Örnek Olay İncelemesi”, 21. YY Türkiye Enstitüsü, http://www.21yyte.org/tr/ arastirma/orta-dogu-ve-afrika-arastirmalari-merkezi/2017/05/10/8627/ teror-orgutleri-ve-propaganda-daes-teror-orgutu-ornek-olayincelemesi, (Erişim Tarihi: 03.01.2018).

\section{İnternet Kaynakları}

"Terör", http://www.tdk.gov.tr/index.php?option=com_bts\&arama=kelime \&guid=TDK.GTS.5a3028e10c5ce2.79615890, (Erişim Tarihi: 31.11.2017). "Terörle Mücadele Kanunu”, http://www.mevzuat.gov.tr/ MevzuatMetin/1.5.3713.pdf, (Erişim Tarihi: 15.01.2018).

“Terörizm", https://www.state.gov/documents/organization/65464.pdf, (Erişim Tarihi: 20.01.2018).

Amerikan Dışişleri Bakanlığı Web Sayfası, "National Strategy for Combating Terrorism" https://www.state.gov/documents/organization/ 60172.pdf, (Erişim Tarihi: 12.01.2018).

1373 saylt Birleşmiş Milletler Güvenlik Konseyi Karart, http://www.uhdigm.adalet.gov.tr/uhamer/Ter\%C3\%B6rle\%20\%C4\% B0lgili\%20Uluslararas\%C4\%B1\%20Belgeler/birle\%C5\%9Fmi\%C5\%9F $\% 20$ milletler/BM\%20G\%C3\%BCvenlik\%20Konseyi\%201373\%20Say\% C4\%B11\%C4\%B1\%20Karar\%C4\%B1.pdf, (Erişim Tarihi: 23.12.2017). GENÇTÜRK, Tuğçe, "Terör Kavramı ve Uluslararası Terörizme Farklı Yaklaşımlar", http://sam.baskent.edu.tr/makaleler/tgencturk/Teror Uluslararasi.pdf, (Erişim Tarihi: 17.01.2018).

"Sultanahmette Canlı Bomba Dehşeti", https://www.sabah.com.tr/ gundem/ 2016/01/13/sultanahmette-canli-bomba-dehseti, (Erişim Tarihi: 18.01.2018).

"Türkiye Büyük Millet Meclisi Başkanlığı Sınıraşan Örgütlü Suçlara Karşı Birleşmiş Milletler Sözleşmesinin Onaylanmasının Uygun Bulunduğuna Dair Kanun”, https://www.tbmm.gov.tr/kanunlar/ 
Uluslararası Terörizmin Değişen Yapısı ve Terör Örgütlerinin

Sosyal Medyayı Kullanması: Suriye'de DAEŞ ve YPG Örneği

k4800.html, (Erişim Tarihi: 21.01.2018).

SAYAR, Kemal, "Terörün Psikolojisi”, http://www.kemalsayar.com/ KatagoriDetay-Terorun-Psikolojisi-37.html, (Erişim Tarihi: 23.02.2018).

"Reina Katliam Davas1 Başlıyor", https://www.ntv.com.tr/turkiye/ reinakatliami-davasi-basliyor,8iI-5e1Bs0qr6u5xnS6fwQ, (Erişim Tarihi: 19.12.2017).

"Sultanahmet saldırısında 1 kişiye tahliye", https://www.birgun.net/ haberdetay/sultanahmet-saldirisi-davasinda-1-kisiye-tahliye-191478.html, (Erişim Tarihi: 19.12.2017).

"Turkey v Syria's Kurds v Islamic State", http://www.bbc.com/news/ world-middle-east-33690060, (Erişim Tarihi: 20.12.2017).

"Meet the Brave Women Fighting ISIS in Syria", https://www.huffington post.com/entry/kurdish-women-fighting-isis_ us_56e05e98e4b065e2e 3 d46569, (Erişim Tarihi: 21.12.2017).

"In pictures: PKK fighters prepare for battle with IS", http://www.bbc. com/news/world-middle-east-33991464, (Erişim Tarihi: 20.12.2017).

Türk Dil Kurumu, http://www.tdk.gov.tr/index.php?option=com_bts\& arama $=$ kelime\& guid=TDK.GTS.5a31a6b0052e38.79567432, (Erişim Tarihi: 29.12.2017).

LERMAN, Kristina, "Social Information Processing in News Aggregation", https://pdfs.semanticscholar.org/2112/386f02791ff207 4a33a341dd1 e523d6e6a97.pdf, (Erişim Tarihi: 02.01.2018).

"Suriye'de Tüyler Ürperten İnfaz", https://www.sabah.com.tr/webtv/ dunya/suriyede-tuyler-urperten-infaz, (Erişim Tarihi: 12.02.2018).

HOFFMAN,Adam, "The Islamic State's Use of Social Media: Terrorism's Siren Song in the Digital Age", http:/daatsolutions.co/inss/wpcontent/uploads/systemfiles/The\%20Islamic\%20State\%E2\%80\%99s\%20U se\%20of\%20Social\%20Media\%20Terrorism\%E2\%80\%99s\%20Siren $\% 20$ Song\%20in\%20the\%20Digital\%20Age\%20\%20Adam\%20Hoffman.pdf, (Erişim Tarihi: 02.02.2018).

"4 Yalan 4 Gerçek", https://www.yenisafak.com/gundem/4-yalan-4gercek-3026136, (Erişim Tarihi: 24.01.2018).

"Al-Qaeda's origins and links", http://news.bbc.co.uk/2/ hi/middle_east/1670089.stm, (Erişim Tarihi: 24.01.2018). 